\title{
The hydrochemistry of a Chalk aquifer during recovery from drought
}

\author{
W G Darling ${ }^{\mathrm{a}}$, D C Gooddy ${ }^{\mathrm{a}}$, B L Morris ${ }^{\mathrm{a}, 1}$ and D W Peach ${ }^{\mathrm{b}}$ \\ ${ }^{a}$ British Geological Survey, Wallingford, OX10 8BB, UK \\ ${ }^{\mathrm{b}}$ British Geological Survey, Keyworth, NG12 5GG, UK \\ Corresponding author e-mail: wgd@ bgs.ac.uk (W.G. Darling). \\ ${ }^{1}$ Present address: 6 Latton Close, Chilton, OX11 0SU, UK
}

\begin{abstract}
Chalk groundwater levels typically decline markedly in response to drought, and rebound strongly when the drought breaks. Chalk streams, largely groundwater-fed, are of ecological importance but little research has been conducted on possible water-quality effects accompanying fluctuations in groundwater level. This study monitored springs, boreholes and surface water in the Pang and Lambourn catchments in southern England during a major recovery in 2006-08. Hydrochemistry, stable isotopes and age indicators were used to characterise the waters. Perennial springs showed little change in water quality over the monitoring period, and even seasonal springs soon became consistent in their hydrochemistry. A similar lack of change was observed in borehole waters and in the River Lambourn. Stable isotopes demonstrated the high degree of damping relative to rainfall inputs, while residence time indicators showed that Chalk groundwater is basically a mixture with an 'old' (pre-1950s) component of $\geq 50 \%$. This being the case, any water quality changes due to water level fluctuations would inevitably become diluted. Therefore, although future climate predictions for southern Britain include greater extremes in rainfall and temperature, and consequently water level changes of greater amplitude, the buffering effect of the Chalk aquifer should protect the quality of Chalk springs and streams.
\end{abstract}

The quality of Chalk groundwater, especially where it issues into surface watercourses from springs, is of some importance both from amenity and regulatory perspectives. With regard to the latter, the EU's Water Framework Directive requires that "good ecological status" and "good chemical status" be maintained or restored (Kallis and Butler, 2001). While the effects of future climate change on the water balance of southern England remain to be established in any detail, it seems likely that there will be more extremes in rainfall and temperature (Hulme et al., 2002). Groundwater flow in the Chalk aquifer occurs very largely through the fracture porosity. The development of this is related to base level changes in response to fluctuations in sea level, resulting in discrete flow horizons separated by much less permeable layers (Butler et al., 2009). This heterogeneous distribution of fracture porosity and permeability means that the aquifer can exhibit major changes in water level in a short period, leading to 
phenomena such as groundwater flooding (Macdonald et al., 2008) and the possibility of changes in water quality. At the same time, the Chalk's high primary porosity has been viewed as having a buffering effect on hydrochemistry (Barker and Foster, 1981).

Although groundwater drought and recovery in the Chalk have received attention in several studies, the present paper is the first to go into significant detail on the water-quality aspects of the cycle. This study addresses the effect of a major rise in water level following an anomalously dry period, primarily by detailed monitoring of a range of spring outlets during the recovery, but with supplementary borehole and river data. A range of environmental indicators has been used, including inorganic chemistry, stable isotopes and age tracers.

\section{Background}

\section{Previous work on Chalk groundwater quality}

There have been various studies on the quality of Chalk streams and groundwaters. These tend to be either one-off 'snapshots' of hydrochemical conditions (e.g. Pitman, 1978; Edmunds et al., 1987; Kloppmann et al., 1998) or the long-term monitoring of nutrients or potential pollutants such as nitrate, mainly in surface waters (e.g. Boar et al., 1995; Hanrahan et al., 2003; Howden and Burt, 2008). The former approach is useful in elucidating the processes giving rise to the characteristic hydrochemistry of the unconfined Chalk aquifer, while the latter although restricted in scope at least may cover periods in which there are large changes in water level (though these are not specifically considered). Neither approach can assess in any detail the effects of drought or recovery on the general inorganic chemical quality of Chalk stream and groundwaters.

Similarly, there have been many studies dealing with water level changes in Chalk aquifers (e.g. Cross et al., 1995; Salmon et al., 1996; Finch et al., 2004), but these are primarily concerned with water supply during times of drought, or conversely the difficulties arising from groundwater flooding. They do not include monitoring of general inorganic water quality. Therefore the scope existed for a study that would address the question of whether 
major changes in groundwater level have any significant effect on Chalk groundwater quality.

\section{Study area}

The area chosen for the recovery water-quality survey comprises the catchments of the rivers Pang and Lambourn, whose hydrology is already known in some detail from the LOCAR programme (Wheater et al., 2006), together with the adjoining north-facing scarp slope of the Berkshire Downs (Fig. 1). There are presently no major groundwater abstractions in the catchments and they are therefore largely free of pumping-related effects on water table elevations. Figure 2 shows a 33-year hydrograph for an interfluve observation borehole (Bradley Wood OBH, NGR 443420 173940) in the Lambourn catchment. This shows that in mid-October 2006 water level was at its lowest since the autumn of 1997, but experienced a greater continuous recovery than followed the 1997 minimum. The interval chosen for spring monitoring (October 2006 to March 2008) included this major recovery phase.

A variety of springs (major, minor, seasonal: Table 1) were chosen to be monitored, locations as given in Fig. 1 and Table 1, with sampling dates as shown in Fig. 2. Further groundwater data were obtained from boreholes in the spring of 2007 and 2008 (details in Table 1). Surface water monitoring was restricted to periodic sampling of the River Lambourn at Boxford (site details in Allen et al., 2010).

While the main aim of the study was to focus on the standard hydrochemical determinands, supplementary sampling of other environmental indicators including dissolved trace gases and stable isotopes was included to assist conceptualisation of the Chalk groundwater system.

\section{Sampling and analysis}

Springs were sampled by means of a $12 \mathrm{~V}$ mini-pump deployed as far below the water surface as possible to minimise the possibility of degassing or contamination by atmospheric gases. Boreholes were sampled either via the installed pump (Stocks Meadow Farm, Rowbury 
Farm, Seven Barrows Stables), or for the remainder of the sites by a portable submersible pump.

Measurements of temperature, $\mathrm{pH}$, alkalinity and dissolved oxygen (DO) were made in the field. Water samples for chemical analysis were passed through a $0.45 \mu \mathrm{m}$ filter and stored as acidified and unacidified splits in HDPE bottles. Trace gas samples were collected and stored using the method of Oster (1994). Stable isotope samples were left unfiltered and stored in glass bottles.

Hydrochemical analysis was carried out by ICP-AES and ion chromatography. Dissolved trace gases (CFCs and $\mathrm{SF}_{6}$ ) were determined by the method of Bullister and Weiss (1988). Stable isotopes were measured by equilibration $\left(\delta^{18} \mathrm{O}\right)$, zinc reduction $\left(\delta^{2} \mathrm{H}\right)$ and acidification $\left(\delta^{13} \mathrm{C}\right.$-DIC), and are reported in the standard $\delta$-notation:

$$
\delta=\left[\left(\mathrm{R}_{\text {sample }} / \mathrm{R}_{\text {standard }}\right)-1\right] \times 10^{3}
$$

where $\mathrm{R}_{\text {sample }}$ is the ${ }^{18} \mathrm{O} /{ }^{16} \mathrm{O},{ }^{2} \mathrm{H} /{ }^{1} \mathrm{H}$ or ${ }^{13} \mathrm{C} /{ }^{12} \mathrm{C}$ ratio of the samples, and $\mathrm{R}_{\text {standard the }}$ corresponding ratio in VSMOW (Vienna Standard Mean Ocean Water) for oxygen and hydrogen, or VPDB (Vienna PeeDee Belemnite) for carbon.

Measurement precisions are within $\pm 0.1 \%$ for $\delta^{18} \mathrm{O}, \pm 1 \%$ for $\delta^{2} \mathrm{H}, \pm 0.2 \%$ for $\delta^{13} \mathrm{C}_{\text {DIC }}$ and $\pm 10 \%$ for the CFCs and $\mathrm{SF}_{6}$, with detection limits of $0.01 \mathrm{pmol} / \mathrm{L}$ (CFC-12), $0.05 \mathrm{pmol} / \mathrm{L}$ (CFC-11) and $0.1 \mathrm{fmol} / \mathrm{L}\left(\mathrm{SF}_{6}\right)$.

\section{Results}

\section{Hydrochemistry}

\section{Springs}

Springs (where flowing) were sampled on eight occasions between October 2006 and March 2008. Hydrochemical data are reported in Table 2. Sampling temperatures ranged from 8.8 
to $12.4^{\circ} \mathrm{C}$, with an average of $10.2^{\circ} \mathrm{C}$, which is typical of the mean annual air temperature in southern England. Values of $\mathrm{pH}$ almost all fell in the range 7.0 to 7.4, typical of Chalk groundwaters. There is no indication that temperature or $\mathrm{pH}$ showed a systematic trend with the recovery in groundwater level; both are more likely to have been dominated by seasonal fluctuations in air temperature at the time of sampling.

Chalk groundwaters are typically well-aerated. To test this for the present study, DO was measured during two sampling rounds. No spring waters were found to contain less than $5 \mathrm{mg} / \mathrm{L}$ of dissolved $\mathrm{O}_{2}$ (Table 2).

Selected solutes are plotted against time in Fig. 3. The water level change in the Bradley Wood borehole is shown for reference on the plot for total organic carbon (TOC). There is on the whole no evidence for significant modification of chemical signatures accompanying the overall rise in water level occurring between October 2006 and April 2008. Alkalinity plotted as $\mathrm{HCO}_{3}$ shows some variation but, like $\mathrm{pH}$ is affected to some extent by air temperature at the time of sampling and therefore not necessarily diagnostic of temporal water quality changes.

The biggest changes in spring water chemistry are associated with the seasonal springs, principally Upton and Lynch Wood. The former commenced flowing with elevated concentrations of $\mathrm{Ca}, \mathrm{Cl}, \mathrm{SO}_{4}$ and TOC. Upton spring occurs in a gully in the middle of agricultural land so it may be that the elevated starting composition was caused by the flushing out of fertiliser or other residues (though $\mathrm{NO}_{3}$ is not elevated). Lynch Wood on the other hand showed starting concentrations slightly dilute compared to the other springs. The woodland setting of the spring might be expected to be largely free of any agrochemicals, but the wood is relatively small and surrounded by agricultural land, so the origin of the low initial concentrations of most ions is not clear. But in the case of both Upton and Lynch Wood, initial high or low concentrations quickly flattened out and were thereafter similar to those from the other springs. Because of the wet autumn and winter conditions from November 2006 onwards, the normally seasonal springs flowed continuously to beyond the end of the monitoring period so no repeat of the flow initiation process could be measured.

Of the perennial springs, Kimber stands out as having the most elevated $\mathrm{Na}$ and $\mathrm{Mg}$ concentrations. This is likely to be due to the input of waters from the Palaeogene sediments 
overlying the Chalk in the Pang catchment, but as with the other springs no secular changes are apparent.

There is on the whole little distinction between scarp and valley springs in their chemical compositions. The one exception noted here is that the scarp slope springs are significantly higher in Si (Fig. 3). For the Woolstone spring complex, which actually issues from the siliceous Malmstone (Upper Greensand) immediately below the base of the Chalk, this is not unexpected. For the remaining scarp springs, all in the Lower Chalk (Fig. 1), the cause of elevated $\mathrm{Si}$ is likely to be related to the relatively high proportion of non-carbonate minerals, which in the Lambourn area are dominated by forms of $\mathrm{SiO}_{2}$ (Morgan-Jones, 1977).

Only one spring (Blewbury) consistently exceeded the drinking water nitrate limit of $11.3 \mathrm{mg} / \mathrm{L}$ as $\mathrm{NO}_{3}-\mathrm{N}$, though the Upton spring some $1.5 \mathrm{~km}$ to the west equally consistently approached the limit. This presumably reflects the intensive arable agriculture of the local area.

Of the minor elements, $\mathrm{Fe}$ and $\mathrm{Mn}$ were almost always below detection and are not reported. Of the others, there was little change in composition during the recovery (Table 2). $\mathrm{Br}$ and $\mathrm{F}$ were found at similar concentrations in both the valley and scarp spring groups, but there were major differences between Ba (typically 70\% lower in the Scarp springs) and $\mathrm{Sr}$ (typically 50\% higher). The reasons for particularly high $\mathrm{Br}$ at Jannaways and $\mathrm{Sr}$ at Woolstone remain unclear, though the latter may be related to the presence of zeolites in the Malmstone as recognised in the nearby Kingston Lisle Borehole (Jeans, 2006).

\section{Boreholes}

Boreholes were sampled twice, in May 2007 and again in March-May 2008. Data are reported in Table 3. The results show no significant change in major or minor elements between the sampling rounds.

One of the boreholes, Barracks Farm, penetrates the saturated zone to a depth of $\sim 90 \mathrm{~m}$ below water table which is some $40 \mathrm{~m}$ greater than any of the other boreholes, probably indicating deepening of the original bore owing to poor inflows further up in the sequence. This and the 
measured low dissolved $\mathrm{O}_{2}$ concentration (Table 3) suggest that much of the water was flowing from the deeper levels in the borehole, conceivably from the zone greater than $50 \mathrm{~m}$ below the water table which Price et al. (1993) considered generally to mark the base of the active flow system in the Chalk. This site therefore can be considered a control unlikely to be affected by short-term groundwater level fluctuations.

\section{River}

The River Lambourn at Boxford was sampled on 21 occasions between November 2006 and March 2008. The hydrochemistry of the river has been described in some detail in Allen et al. (2010) so the data are not reported here in tabular form. Instead, major species are plotted with time in Fig. 4. Also shown is the monthly rainfall amount for Wallingford some $30 \mathrm{~km}$ to the ENE, the monthly discharge of the river as measured at the gauging station at Shaw just above the confluence with the River Kennet, and the groundwater recovery record from the Bradley Wood OBH.

There was little response of the river to rainfall at the monthly scale, and also little response of river water quality to the recovery from drought. The minor species $\mathrm{Ba}, \mathrm{Sr}, \mathrm{Br}, \mathrm{F}$ and $\mathrm{P}$ are not shown but showed an equal lack of response to the recovery. This was also found to be the case for dissolved organic carbon (DOC) as measured by Lapworth et al. (2009).

\section{Stable isotopes}

\section{Water}

The $\delta^{18} \mathrm{O}$ composition of most springs for much of the time was very similar (Fig. 5a), varying little outside measurement error. This was also the case for the boreholes (Fig. 5b) and the River Lambourn at Boxford (Fig. 5c). In the latter case the monthly $\delta^{18} \mathrm{O}$ precipitation input signal as recorded at Wallingford (http://www.univie.ac.at/cartography/project/wiser/index.php) is included to demonstrate the high degree of damping shown by all the waters. This accords with the findings of Lawler (1987) who monitored the river for a similar length of time some 25 years previously. 


\section{Dissolved inorganic carbon}

The $\delta^{13} \mathrm{C}$ content of DIC (dissolved inorganic carbon, effectively $\mathrm{HCO}_{3}{ }^{-}$at the $\mathrm{pH}$ of Chalk waters) in the spring waters typically lay between -12 and $-16.5 \%$, with an average of $-14.84 \%$ o and a standard deviation of $0.87 \%$. There was a tendency towards slight isotopic depletion during the two winters covered (Fig. 6a) suggesting the influence of temperature on composition. The major departure from the general trend was shown by the first sample from the Letcombe spring, which also showed the most enriched $\delta^{18} \mathrm{O}$ composition, suggesting some local perturbation in the shallow system due to the drought.

As with $\delta^{18} \mathrm{O}$, borehole $\delta^{13} \mathrm{C}$ values were similar for the samplings of 2007 and 2008, with an average value of $-14.09 \%$ with standard deviation of 1.03\% (Fig. 6b). The Barracks Farm water was the isotopically heaviest probably because of scope for development of precipitation-redissolution processes in this relatively immobile water (see above).

River water $\delta^{13} \mathrm{C}$ values over the course of about one hydrological year were generally in the range -13 to $-15 \%$ o but peak at $-11 \%$ in March 2008 (Fig. 6c). The general overlap with the springs is not unexpected as the river is almost completely groundwater-fed, though it does indicate a lack of re-equilibration with atmospheric $\mathrm{CO}_{2}$. The mid-March peak may mark the onset of photosynthesis in the water column, which preferentially selects ${ }^{12} \mathrm{C}$ (Schulte et al., 2011).

\section{Trace gas age indicators}

The chlorofluorocarbons CFC-11 and CFC-12 together with sulphur hexafluoride $\left(\mathrm{SF}_{6}\right)$ were measured in groundwaters (Table 4). The theory behind the application of these age indicators is reviewed by Plummer and Busenberg (1999) and Busenberg and Plummer (2000).

With well-constrained mean annual air temperature and recharge altitude, the only correction necessary for the samples is to account for the excess air which is always present to some extent in groundwater. Gooddy et al. (2006) reported an average excess air content of 
$2.5 \mathrm{ccSTP} / \mathrm{L}$ in groundwaters at Boxford in the Lambourn. At this relatively low concentration it is unnecessary to correct $\mathrm{CFC}$ values, but $\mathrm{SF}_{6}$ concentrations do require adjustment to provide more accurate age information (Darling et al., in press). The corrected values in Table 4 use a factor of 0.79 based on the above value for excess air.

Table 5 converts the measured $\mathrm{CFC}-12$ and $\mathrm{SF}_{6}$ concentrations from Table 4 in two fundamentally different ways: firstly as a piston-flow (PF) age (i.e. assuming travel as a discrete pulse of water), and secondly as a modern fraction (i.e. the amount of young water mixing with pre-CFC or $\mathrm{SF}_{6}$ water at least several decades old). As a dual-porosity aquifer (Price et al.1993), the unconfined Chalk is more likely to behave in the latter way but the PF age provides at least a qualitative indication of groundwater mean residence time. Where measured concentrations of $\mathrm{CFC}-12$ exceed the maximum air-equilibrated water (AEW) value of $3.0 \mathrm{pmol} / \mathrm{L}$ they result in a modern fraction value $>1$ and therefore cannot be used to calculate a residence time. No $\mathrm{SF}_{6}$ concentrations exceed the $\mathrm{AEW}$ value and these can therefore be used to calculate apparently realistic modern fraction and residence time values (Table 5, Fig. 7). Note that the AEW values for $\mathrm{SF}_{6}$ increase slightly each year because of the steady rise in atmospheric concentration of the gas.

It is apparent from Table 5 and Fig. 7 that some springs were consistently high in CFC-12 (Kimber, Weston, Blewbury and Upton). The latter two scarp springs are situated downflow of the Harwell Science and Engineering Centre where chlorinated solvent disposal to the ground was practised for several decades (Muldoon et al., 1998), which is a possible cause of the CFC excess. However, the CFC-12 excess was of the same order for Kimber Spring in the Pang catchment, which in this case cannot be linked to such an obvious potential source of contamination. The Chalk aquifer in general tends to suffer from varying degrees of CFC contamination (e.g. Darling et al., 2005).

For the remaining springs, even where CFC-12 modern fractions $<1$ are observed for springs, minor contamination cannot be ruled out. The best agreement between CFC-12 and $\mathrm{SF}_{6}$ was found in the more westerly scarp springs, where contamination is least likely because the catchments are small and without significant centres of population. In these springs it is the modern fraction values rather than the PF ages that match best (Table 5). 


\section{Discussion}

\section{Water quality}

The absence of significant change during water level recovery in the hydrochemistry of spring, borehole and river waters has already been noted. While it could be anticipated that borehole waters would show rather little change, spring and river waters might have been expected to show any recovery-related variations either during or soon after the recovery period. Given that monitoring for this study continued for a further year after the main recovery, it is unlikely that any moderate-to-major changes in water quality have been missed.

Comparison of the mean major ion concentrations in the four different water types (valley springs, scarp springs, river water and borehole waters) reveals a remarkably similar distribution (Fig. 8). This homogeneity suggests that either infiltrating recharge to the Chalk aquifer very rapidly acquires a groundwater-like composition, or that there is enough mixing within the aquifer to mask any variations in input. Notwithstanding the existence of a certain amount of 'bypass' flow in the Chalk unsaturated zone (e.g. Mathias et al., 2006), it is known from lysimeter studies that by $5 \mathrm{~m}$ below ground surface, waters are well-mixed chemically and isotopically (Darling and Bath, 1988; Van den Daele et al., 2007). This, combined with the Chalk's high porosity and a capillary fringe typically extending many tens of metres above the water table (Price et al., 1993), implies that water quality is very largely fixed before the water even reaches the water table, except for carbonate-system effects such as the sharp rise in alkalinity observed for some springs during the early part of the recovery, perhaps related to temporarily-elevated $p \mathrm{CO}_{2}$ due to the onset of recharge. Otherwise, the only constituents likely to rise somewhat after this point are those whose dissolution takes more time, e.g. Si from slowly-dissolving silicate minerals.

The same consistency shown by the major ions extends to the minor elements in the valley and scarp spring groups, with the exceptions of $\mathrm{Ba}$ and $\mathrm{Sr}$ noted above (4.1.1). Why $\mathrm{Sr}$ should be higher in the scarp springs remains unclear, especially since the proportion of $\mathrm{Sr}$ in the solid phase of the Chalk drops by about half between the Upper Chalk and the Lower Chalk (Pearce et al., 2003) in which the scarp springs are mostly situated. Since Ba normally 
behaves geochemically in a similar way to $\mathrm{Sr}$, the divergence between the two is also hard to explain. It does not appear to be related to solubility controls as all waters are well below saturation with respect to $\mathrm{Sr}$ and $\mathrm{Ba}$ carbonates. Nevertheless, changes in $\mathrm{Sr}$ relative to $\mathrm{Ca}$ and $\mathrm{Mg}$ do imply the existence of different processes contributing to the water quality of the valley and scarp springs. A plot of $\mathrm{Sr} / \mathrm{Ca}$ versus $\mathrm{Mg} / \mathrm{Ca}$ reveals two separate trends (Fig. 9). The scarp spring trend is typical of incongruent dissolution of chalk (e.g. Gillon et al., 2012), and culminates in maximum proportions of $\mathrm{Sr}$ and $\mathrm{Mg}$ in the Woolstone spring. For this site, the pre-recovery (October 2006) sample is the most evolved and probably oldest water. (This cannot be confirmed by trace gas dating because flow from the spring was too low to permit the necessary sampling process.) By contrast, the valley springs acquire much less Sr with rise in $\mathrm{Mg} / \mathrm{Ca}$, indicating that a different process predominates. The composition of local Palaeogene springs strongly suggests that mixing with water from overlying strata is affecting some of the Chalk springs. Kimber spring has the highest $\mathrm{Mg} / \mathrm{Ca}$ ratios, and Fig. 1 shows that it is situated on the edge of the Palaeogene outcrop and therefore very likely to be receiving some Palaeogene water (which accords with hydrograph evidence: Wheater et al., 2006). The pre-recovery sample from Kimber is relatively depleted in $\mathrm{Mg}$ which implies that the contribution from the Palaeogene had reached a low point by the end of the drought.

The general absence of excessive nitrate concentrations in this area of the Chalk has been noted earlier. However, in many arable catchments there is a significant input of nitrate from fertiliser leading to a so called 'time-bomb' effect (Wang et al., 2012) which has been linked to a rising trend in long-term groundwater (Rivett et al., 2007; Stuart et al. 2007) and river concentrations (Howden et al., 2011). Therefore with regard to nitrate, a certain amount of caution needs to be taken in extrapolating the findings of the present study to other Chalk catchments, where additional factors may require consideration (see e.g. Whitehead et al., 2006; Rivett et al., 2008).

\section{Groundwater flow, mixing and residence time}

It has been noted above that the least solvent-contaminated waters were found in the western escarpment springs. For these springs, a co-plot of $\mathrm{CFC}-12$ versus $\mathrm{SF}_{6}$ should provide an indication of the fundamental nature of flow or mixing processes in the aquifer (Darling et 
al., in press). Figure 10 shows this for Letcombe Bassett and Woolstone, the two apparently least-contaminated springs. The waters plot as an array centred on the mixing line between recent recharge and older, pre-1950s groundwater. While other modes of flow may occur under certain circumstances, it appears likely that mixing is indeed an important mechanism in governing the quality of Chalk groundwaters.

On this basis, all the spring waters are compared for their successive $\mathrm{SF}_{6}$ modern fractions in Fig. 11a. This reveals several features. Kimber and Letcombe spring waters were most restricted in composition, suggesting that these springs are fed by large, well-mixed reservoirs of groundwater. The Kimber-Blue Pool spring complex is notable as the dominant point-source contribution to the River Pang throughout the year, while the Letcombe spring complex also has a high discharge. In contrast, the smallest outlet sampled (Weston) showed the greatest variation, followed by the seasonal springs of East Garston, Lynch Wood and Upton. Despite these differences between springs, it may be noted that with the exception of Jannaways, all the modern fractions at the start of the monitoring period, or when the seasonal springs started flowing again, lay towards the middle of the monitoring range. While this might be expected for the permanent springs, it is perhaps more noteworthy for the seasonal springs, where it implies that the rising water table contained water that was already well-mixed.

Figure 11a also indicates that there was a tendency for springs to show a bias towards higher modern fraction in February and March 2007, i.e. late on in the recovery, presumably resulting from the influx of younger water, and showing that the mixing process is not totally consistent. Once this pulse has passed through however, most spring waters, particularly on the scarp, gave modern fractions at the low end of their range a year later in March 2008.

Figure $11 \mathrm{~b}$ reduces the $\mathrm{SF}_{6}$ modern fraction data to basic statistics. It is apparent that the amount of mixing covers a similar range in both the valley and scarp springs $(\sim 0.35-0.55$ modern fraction), with almost identical mean and median values. The greater overall range of the valley springs may reflect the preservation of sub-karstic features on the dip-slope (Banks et al., 1995; Maurice et al., 2006) which allow more mixing to occur locally.

In terms of simple mean residence times based on $\mathrm{SF}_{6}$ concentrations (Table 5), both valley and scarp spring waters average out at $\sim 15$ years. This would explain why only background 
tritium activities were found in scarp springs sampled in 1967 by Paterson (1971), i.e. a few years after the thermonuclear ${ }^{3} \mathrm{H}$ peak of the mid-1960s. The similar mean ages might imply flow paths of similar length, but it is apparent from Fig. 1 that horizontal distances from the water divide to the springs are potentially much greater for the valley springs than for the scarp springs, for which Patterson (1971) estimated a maximum of only $1.2 \mathrm{~km}$. It may simply be that there is a degree of bedding-related hydraulic anisotropy favouring more rapid transport to the valley springs.

\section{Implications for climate change}

It should be noted that the drought terminating in 2006 was not the most severe of recent times, that description being generally applied to the 1976 drought (Marsh et al, 2007). Nevertheless, the hydrograph in Figure 2 shows that the minimum water level in the Bradley Wood borehole in 1976 was only $\sim 1$ m lower than the 2006 minimum, while the 2006-07 recovery was almost identical in water level rise to the 1976-77 recovery (both $\sim 6 \mathrm{~m}$ ). Therefore it is considered that the 2006-07 recovery represents a reasonably good test of Chalk aquifer resilience in historical terms.

The evidence considered above indicates that short- to medium-term fluctuations in Chalk groundwater levels are unlikely to lead to significant changes in the inorganic chemical quality of groundwaters or streams with a high baseflow index. The high storage and damping potential of the Chalk means that the aquifer would have to be significantly stressed over a long period before any changes in quality of spring waters were likely to occur. If average water levels dropped irreversibly by tens of metres then it is possible that the presently relatively immobile water from the deeper parts of the aquifer would become incorporated into the active flow system, secondary (fracture) permeability permitting. On the assumption that the analyses from the Barracks borehole are typical of this water, changes in inorganic chemical quality would be minimal (Table 3). In any case, such a drastic lowering of the water table would be likely to cause both springs and streams to stop flowing altogether, which would be a much greater issue for "good ecological status". However, given the forecast of greater extremes in rainfall and temperature as the climate changes 
(Hulme et al., 2002), it seems more probable that there will simply be a rather greater variation in groundwater levels around something close to the present mean.

This suggests a business-as-usual scenario for Chalk groundwater quality. Only if climate change were to result in significant modifications to agricultural practices on the catchments might more profound changes in water quality be anticipated (Bloomfield et al., 2006; Green et al., 2011).

\section{Conclusions}

A major recovery in Chalk groundwater levels has been monitored at sites in two neighbouring catchments in southern England. The intention of this study was to determine the recovery's effect on the quality of spring and river waters, as a guide to what changes in the Chalk aquifer generally could be expected under likely future climate conditions. In addition to inorganic hydrochemistry, other environmental tracers were used to better understand how the chosen catchments function. The whole dataset will provide a comprehensive baseline for future studies.

Hydrochemical changes were small, with almost identical average compositions noted for spring, borehole and river waters and no consistent indications of recovery-related change, though minor element evidence could distinguish processes at work in scarp and valley springs. Stable $\mathrm{O}$ and $\mathrm{H}$ isotopes indicated extreme damping of rainfall inputs, while minor changes in carbon stable isotopes were probably seasonal in nature.

Trace-gas residence time indicators appeared to support other lines of evidence that it is appropriate to view unconfined Chalk groundwaters as the product of mixing rather than piston flow. Springs had very consistent proportions of old groundwater mainly in the range $50-60 \%$, even on commencement of flow after the start of the recovery, indicating the extent to which groundwater is already well mixed as water levels rise.

While the climate-change forecast for Britain is for greater extremes in rainfall and temperature, making it likely the Chalk will experience rather greater variations in 
groundwater level around the present mean, the results of this study suggest that the status quo in groundwater quality in the Chalk aquifer is likely to be maintained.

Acknowledgements. The owners and tenants of the farm boreholes and the Environment Agency as custodians of the observation boreholes are thanked for their cooperation over sampling. British Geological Survey colleagues, particularly Debbie Allen, are acknowledged for their collection of river water samples at Boxford. The authors are grateful to Tim Atkinson, Adrian Butler and Assistant Editor Jonathan Smith for their helpful review comments. This paper is published with the permission of the Executive Director, British Geological Survey (NERC). 


\section{References}

Allen D J, Darling W G, Gooddy D C, Lapworth D J, Newell A J, Williams A T, Allen D and Abesser C, 2010. Interaction between groundwater, the hyporheic zone and a Chalk stream: a case study from the River Lambourn, UK. Hydrogeology Journal 18, 1431-2174.

Banks D, Davies C and Davies W, 1995. The Chalk as a karstic aquifer: evidence from a tracer test at Stanford Dingley, Berkshire, UK. Quarterly Journal of Engineering Geology and Hydrogeology 28, Supplement, S31-S38.

Barker J A and Foster S S D, 1981. A diffusion exchange model for solute movement in fissured porous rock. Quarterly Journal of Engineering Geology and Hydrogeology 14, 1724.

Bloomfield J P, Williams R J, Gooddy D C, Cape J N and Guha P, 2006. Impacts of climate change on the fate and behaviour of pesticides in surface and groundwater - a UK perspective. Science of the Total Environment 369, 163-177.

Boar R R, Lister D H and Clough W T, 1995. Phosphorus loads in a small groundwater-fed river during the 1989-1992 East Anglian drought. Water Research 29, 2167-2173.

Bullister J L and Weiss R F, 1988. Determination of CC13F and CC12F2 in seawater and air. Deep Sea Research 35, 839-853.

Busenberg E and Plummer L N, 2000. Dating young groundwater with sulfur hexafluoride: natural and anthropogenic sources of sulfur hexafluoride. Water Resources Research 36, 3011-3030.

Butler A P, Mathias S A, Gallagher A J, Peach D W and Williams A T, 2009. Analysis of flow processes in fractured chalk under pumped and ambient conditions (UK), Hydrogeology Journal 17, 1848-1858.

Cross G A, Rushton K R, Tomlinson L M, 1995. The East Kent Chalk Aquifer during the 1988-92 drought. Water and Environment Journal 9, 37-48.

Darling W G and Bath A H, 1988. A stable isotope study of recharge processes in the English Chalk . Journal of Hydrology 101, 31-46.

Darling W G, Morris B L, Stuart M E and Gooddy D C, 2005. Groundwater age indicators from public supplies tapping the Chalk aquifer of Southern England. Water and Environment Journal 19, 30-40.

Darling W G, Gooddy D C, MacDonald A M and Morris B L, 2012. The practicalities of using $\mathrm{CFCs}_{\text {and }} \mathrm{SF}_{6}$ for groundwater dating and tracing. Applied Geochemistry 27, 16881697. 
Edmunds W M, Cook J M, Darling W G, Kinniburgh D G, Miles D L, Bath A H, Morgan Jones M and Andrews J N, 1987. Baseline geochemical conditions in the Chalk aquifer, Berkshire, UK: a basis for groundwater quality management. Applied Geochemistry 2, 251274.

Finch J W, Bradford R B and Hudson J A, 2004. The spatial distribution of groundwater flooding in a chalk catchment in southern England. Hydrological Processes 18, 959-971.

Gillon M, Renard F, Crançon P and Aupiais J. 2012. Kinetics of incongruent dissolution of carbonates in a Chalk aquifer using reverse flow modelling. Journal of Hydrology 420-421, 329-339.

Gooddy D C, Darling W G, Abesser C and Lapworth D J, 2006. Using chlorofluorocarbons (CFCs) and sulphur hexafluoride $\left(\mathrm{SF}_{6}\right)$ to characterise groundwater movement and residence time in a lowland Chalk catchment. Journal of Hydrology 330, 44-52.

Green T, Taniguchi M, Kooi H, Gurdak J J, Hiscock K, Allen D, Treidel H and Aurelia A, 2011. Beneath the surface of global change: Impacts of climate change on groundwater. Journal of Hydrology 405, 532-560.

Hanrahan G, Gledhill M, House W A and Worsfold P J, 2003. Evaluation of phosphorus concentrations in relation to annual and seasonal physico-chemical water quality parameters in a UK chalkstream. Water Research 37, 3579-3589.

Howden N J K and Burt T P, 2008. Temporal and spatial analysis of nitrate concentrations from the Frome and Piddle catchments in Dorset (UK) for water years 1978 to 2007: Evidence for nitrate breakthrough? Science of The Total Environment 407, 507-526.

Howden N J K, Burt T P, Worrall F, Mathias S and Whelan M J, 2011. Nitrate pollution in intensively farmed regions: What are the prospects for sustaining high-quality groundwater?, Water Resour. Res. 47, W00L02.

Hulme M, Jenkins G J, Lu X, Turnpenny J R, Mitchell T D, Jones R G, Lowe J, Murphy J M, Hassell D, Boorman P, McDonald R and Hill S, 2002. Climate change scenarios for the United Kingdom: the UKCIP02 scientific report. Tyndall Centre for Climate Change Research, University of East Anglia, Norwich, UK.

Jeans C V, 2006. Clay mineralogy of the Cretaceous strata of the British Isles. Clay Minerals 41, 47-150.

Kallis G, Butler D, 2001. The EU water framework directive: measures and implications. Water Policy 3, 125-142.

Kloppmann W, Dever L and Edmunds W M, 1998. Residence time of Chalk groundwaters in the Paris Basin and the North German Basin: a geochemical approach Applied Geochemistry 13, 593-606. 
Lapworth D J, Gooddy D C, Allen D and Old G H, 2009. Understanding groundwater, surface water, and hyporheic zone biogeochemical processes in a Chalk catchment using fluorescence properties of dissolved and colloidal organic matter. Journal of Geophysical Research 114, G00F02, doi:10.1029/2009JG000921.

Lawler H A, 1987. Sampling for isotopic responses in surface waters. Earth Surface Processes and Landforms 12, 551-559.

Macdonald D M J, Bloomfield J P, Hughes A G, MacDonald A M, Adams B and McKenzie A A, 2008. Improving the understanding of the risk from groundwater flooding in the UK. In: FLOODrisk 2008, European Conference on Flood Risk Management, Oxford, UK, 30 Sept 2 Oct 2008. The Netherlands, CRC Press.

Marsh T J, Cole GA and Wilby R L, 2007. Major droughts in England and Wales, 18002006. Weather 62, 87-93.

Mathias S A, Butler A P, Jackson B M and Wheater H S, 2006. Transient simulations of flow and transport in the Chalk unsaturated zone. Journal of Hydrology 330, 10-28.

Maurice L D, Atkinson T C, Barker J A, Bloomfield J P, Farrant A R and Williams A T, 2006. Karstic behaviour of groundwater in the English Chalk. Journal of Hydrology 330, 6370.

Morgan-Jones, M, 1977. Mineralogy of the non-carbonate material from the Chalk of Berkshire and Oxfordshire. Clay Minerals 12, 331-343.

Muldoon D G, Connolly P J, Makovitch A W, Holden J M W and Tunstall-Pedoe N, 1998. Groundwater remediation of chlorinated hydrocarbons at an electronics manufacturing facility in northeastern USA. Geological Society, London, Special Publication 128, 183-200.

Oster H, 1994. Datierung von Grundwasser mittels FCKW: Voraussetzungen, Möglichkeiten und Grenzen. Dissertation, Universität Heidelberg.

Paterson K, 1971. Some considerations concerning percolation waters in the Chalk of North Berkshire. Cave Research Group of Great Britain Transactions 13, 277-282.

Pearce M A, Jarvis I, Swan A R H, Murphy A M, Tocher B A and Edmunds W M, 2003. Integrating palynological and geochemical data in a new approach to palaeoecological studies: Upper Cretaceous of the Banterwick Barn Chalk borehole, Berkshire, UK. Marine Micropaleontology 47, 271-306.

Pitman J J, 1978. Carbonate chemistry of groundwater from chalk, Givendale, East Yorkshire. Geochimica et Cosmochimica Acta 42, 1885-1897.

Plummer L N and Busenberg E, 1999. Chlorofluorocarbons. In: P G Cook and A L Herczeg (eds), Environmental Tracers in Subsurface Hydrology, Kluwer, Dordrecht, 441-478. 
Price M, Downing R A and Edmunds W M, 1993. The Chalk as an aquifer. In: The Hydrogeology of the Chalk of North-West Europe, R A Downing, M Price, G P Jones (Eds.), Oxford Science Publications, Clarendon Press, Oxford, UK (1993), 35-58.

Rivett M O, Smith J W N, Buss S R and Morgan P, 2007. Nitrate occurrence and attenuation in the major aquifers of England and Wales, Quarterly Journal of Engineering Geology and Hydrogeology 40, 335-352.

Rivett M O, Buss S R, Morgan P, Bemment C D, and Smith J W N, 2008. Nitrate attenuation in groundwater: Review of biogeochemical controlling processes. Water Research 42, 42154232. Salmon S, Chadha D and Smith D, 1996. Development of a Groundwater Resource Model for the Yorkshire Chalk. Water and Environment Journal 10, 413-422.

Schulte P, van Geldern R, Freitag H, Karimb A, Négrele P, Petelet-Giraude E, Probst A, Probst J-L, Telmer K, Veizer J and Barth J A C, 2011. Applications of stable water and carbon isotopes in watershed research: Weathering, carbon cycling, and water balances. Earth-Science Reviews 109, 20-31.

Stuart M E, Chilton P J, Kinniburgh D G and Cooper D M, 2007. Screening for long-term trends in groundwater nitrate monitoring data. Quarterly Journal of Engineering Geology and Hydrogeology 40, 361-376.

Van den Daele G F A, Barker J A, Connell L D, Atkinson T C, Darling W G and Cooper J D, 2007. Unsaturated flow and solute transport through the Chalk: Tracer test and dual permeability modelling. Journal of Hydrology 342, 157-172.

Wang L, Stuart M E, Bloomfield J P, Butcher A S, Gooddy D C, McKenzie A A, Lewis M A and Williams A T, 2012. Prediction of the arrival of peak nitrate concentrations at the water table at the regional scale in Great Britain. Hydrological Processes 26, 226-239.

Wheater H S, Neal C and Peach D W, 2006. Hydro-ecological functioning of the Pang and Lambourn catchments, UK; an introduction to the Special Issue. Journal of Hydrology 330, $1-9$.

Whitehead PG, Wilby R L, Butterfield D and Wade A J, 2006. Impacts of climate change on in-stream nitrogen in a lowland chalk stream: An appraisal of adaptation strategies. Science of The Total Environment 365, 260-273. 
Table 1 Location data and details for spring, borehole and river sampling sites.

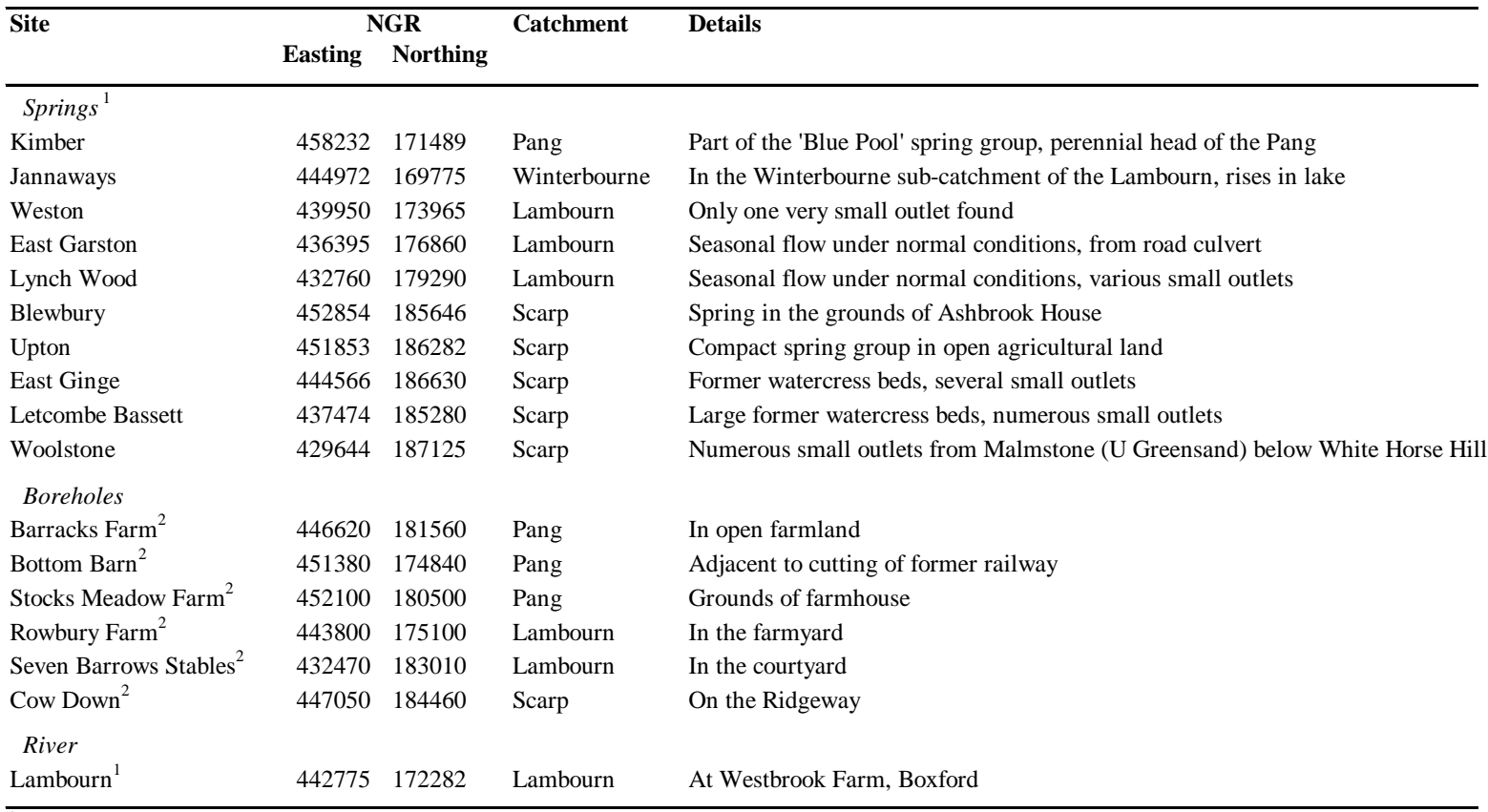

${ }^{1}$ Sampled periodically October 2006 - March 2008

${ }^{2}$ Sampled in March 2007 and May 2008 
Table 2. Field measurements and major and minor ion chemistry of spring waters.

DO - dissolved oxygen, TOC - total organic carbon.

\begin{tabular}{|c|c|c|c|c|c|c|c|c|c|c|c|c|}
\hline Site & ${ }^{\circ} \mathbf{C}$ & & $\mathrm{mg} / \mathrm{L}$ & $\mathrm{mg} / \mathrm{L}$ & $\mathrm{mg} / \mathrm{L}$ & $\mathrm{mg} / \mathrm{L}$ & $\mathrm{mg} / \mathrm{L}$ & $\mathrm{mg} / \mathrm{L}$ & $\mathrm{mg} / \mathrm{L}$ & $\mathrm{mg} / \mathrm{L}$ & $\mathrm{mg} / \mathrm{L}$ & $\mathrm{mg} / \mathrm{L}$ \\
\hline 31-Oct-06 & Temp & pH & DO & $\mathrm{Ca}$ & Mg & $\mathrm{Na}$ & $\mathbf{K}$ & $\mathrm{HCO}_{3}$ & $\mathrm{Cl}$ & $\mathrm{SO}_{4}$ & $\mathrm{NO}_{3}-\mathrm{N}$ & $\mathrm{Si}$ \\
\hline Kimber & 11.1 & 7.01 & - & 105 & 2.82 & 10.6 & 2.39 & 271 & 20.9 & 16.4 & 7.7 & 8.3 \\
\hline Jannaways & 11.5 & 7.03 & - & 105 & 2.07 & 9.77 & 2.73 & 250 & 19.3 & 16.8 & 7.1 & 6.8 \\
\hline Weston & 10.7 & 7.24 & - & 100 & 1.52 & 7.27 & 1.43 & 244 & 17.6 & 12.6 & 8.9 & 7.6 \\
\hline $\begin{array}{l}\text { E Garston } \\
\text { Lynch Wd }\end{array}$ & & & & & & & & & $\begin{array}{l}\text { sp r } \\
\text { sp r }\end{array}$ & $\begin{array}{ll}n \mathrm{~g} & \mathrm{no} \\
\mathrm{n} & \mathrm{g} \\
\mathrm{no}\end{array}$ & $\begin{array}{l}\mathrm{f} \text { flow } \\
\text { t } 110 \mathrm{w}\end{array}$ & $\begin{array}{l}\text { in } g \\
\text { in } g\end{array}$ \\
\hline $\begin{array}{l}\text { Blewbury } \\
\text { Upton }\end{array}$ & 10.6 & 6.98 & - & 129 & 2.1 & 6.90 & 2.32 & 240 & $\begin{array}{c}28.2 \\
-\mathrm{spr}\end{array}$ & $\begin{array}{c}48.6 \\
\mathrm{n} g \mathrm{no}\end{array}$ & $\begin{array}{l}12.2 \\
\mathrm{f} 1 \mathrm{ow}\end{array}$ & $\begin{array}{l}12.3 \\
\mathrm{i} \mathrm{g}\end{array}$ \\
\hline Ginge & 10.7 & 7.03 & - & 107 & 1.73 & 9.07 & 2.87 & 246 & 20.7 & 16.2 & 5.7 & 12.8 \\
\hline Letcombe B. & 10.4 & 7.15 & - & 89.9 & 1.40 & 6.21 & 1.43 & 230 & 11.2 & 12.2 & 4.7 & 12.5 \\
\hline Woolstone & & 7.19 & - & 105 & 2.77 & 11.5 & 3.36 & 228 & 26.9 & 46.9 & 3.8 & 13.8 \\
\hline 30-Nov-06 & Temp & pH & DO & Ca & Mg & $\mathrm{Na}$ & $\mathbf{K}$ & $\mathrm{HCO}_{3}$ & Cl & $\mathrm{SO}_{4}$ & $\mathrm{NO}_{3}-\mathrm{N}$ & $\mathbf{S i}$ \\
\hline Kimber & 10.4 & & - & 99.2 & 3.45 & 11.5 & 2.85 & 245 & 23.0 & 20.4 & 7.8 & 7.7 \\
\hline Jannaways & 10.0 & 7.16 & - & 115 & 2.15 & 10.5 & 2.46 & 256 & 21.9 & 16.2 & 7.9 & 7.0 \\
\hline Weston & 9.9 & 7.16 & - & 105 & 1.62 & 7.77 & 1.39 & 260 & 19.4 & 13.1 & 10.1 & 7.5 \\
\hline $\begin{array}{l}\text { E Garston } \\
\text { Lynch Wd }\end{array}$ & & & & & & & & & & $\begin{array}{ll}n \mathrm{~g} & \mathrm{no} \\
\mathrm{n} g & \mathrm{no}\end{array}$ & $\begin{array}{l}t \text { flow } \\
\text { t flow }\end{array}$ & $\begin{array}{l}\text { in } g \\
\text { i n } g\end{array}$ \\
\hline Blewbury & 10.4 & 7.05 & - & 126 & 2.13 & 7.12 & 2.57 & 250 & 29.4 & 48.5 & 12.4 & 12.2 \\
\hline Upton & 10.8 & 7.25 & - & 163 & 2.95 & 13.1 & 3.05 & 274 & 71.6 & 82.7 & 10.1 & 13.4 \\
\hline Ginge & 10.8 & 7.06 & - & 108 & 1.81 & 8.46 & 2.98 & 262 & 19.2 & 16.9 & 6.2 & 12.3 \\
\hline Letcombe B. & 10.0 & 7.15 & - & 96.3 & 1.57 & 6.78 & 1.57 & 226 & 12.1 & 13.4 & 5.0 & 11.6 \\
\hline Woolstone & 10.5 & 7.12 & - & 104 & 2.17 & 7.34 & 2.55 & 223 & 21.3 & 35.1 & 6.4 & 12.6 \\
\hline 04-Jan-07 & Temp & pH & DO & $\mathrm{Ca}$ & Mg & $\mathrm{Na}$ & $\mathbf{K}$ & $\mathrm{HCO}_{3}$ & Cl & $\mathrm{SO}_{4}$ & $\mathrm{NO}_{3}-\mathrm{N}$ & $\mathbf{S i}$ \\
\hline Kimber & 10.9 & 7.12 & - & 107 & 3.56 & 11.8 & 2.97 & 281 & 24.2 & 21.3 & 8.3 & 7.6 \\
\hline Jannaways & 10.8 & 7.15 & - & 115 & 2.14 & 9.8 & 2.25 & 250 & 21.8 & 15.0 & 8.1 & 7.0 \\
\hline Weston & 10.6 & 6.98 & - & 109 & 1.84 & 7.51 & 2.10 & 306 & 18.3 & 14.2 & 9.3 & 8.0 \\
\hline E Garston & 10.0 & 7.15 & - & 98.9 & 1.62 & 6.28 & 1.19 & 242 & 15.9 & 16.9 & 10.0 & 9.0 \\
\hline Lynch Wd & 9.9 & 7.20 & - & 69.0 & 1.00 & 4.01 & 0.72 & 224 & 9.14 & 11.9 & 4.7 & 6.1 \\
\hline Blewbury & 10.7 & 6.96 & - & 132 & 2.11 & 7.07 & 2.37 & 284 & 28.8 & 46.0 & 13.0 & 12.1 \\
\hline Upton & 11.3 & 7.16 & - & 138 & 2.21 & 8.00 & 2.20 & 262 & 38.6 & 44.1 & 13.4 & 12.7 \\
\hline Ginge & 10.5 & 6.97 & - & 115 & 2.05 & 6.37 & 3.18 & 299 & 14.0 & 18.9 & 8.5 & 11.7 \\
\hline Letcombe B. & 9.5 & 7.14 & - & 94.3 & 1.51 & 6.37 & 1.52 & 290 & 11.3 & 13.4 & 5.2 & 11.5 \\
\hline Woolstone & 10.6 & 7.26 & - & 108 & 2.38 & 12.3 & 3.11 & 235 & 29.6 & 33.3 & 4.6 & 12.9 \\
\hline 06-Feb-07 & Temp & pH & DO & $\mathbf{C a}$ & Mg & $\mathrm{Na}$ & $\mathbf{K}$ & $\mathrm{HCO}_{3}$ & Cl & $\mathrm{SO}_{4}$ & $\mathrm{NO}_{3}-\mathrm{N}$ & $\mathbf{S i}$ \\
\hline Kimber & 10.3 & 7.10 & 6.24 & 107 & 3.61 & 11.4 & 2.8 & 260 & 23.7 & 20.7 & 8.7 & 8.0 \\
\hline Jannaways & 9.8 & 7.06 & 8.26 & 120 & 2.27 & 9.42 & 2.37 & 290 & 19.3 & 16.5 & 8. & 7.4 \\
\hline ton & 9.8 & 7.12 & 8.14 & 115 & 1.98 & 8.37 & 2.24 & 274 & 18.4 & 15.0 & 9.1 & 8. \\
\hline E Garston & 9.8 & 7.22 & 10.10 & 99.7 & 1.76 & 6.13 & 1.58 & 232 & 14.1 & 15.5 & 9.8 & 9. \\
\hline Lynch Wd & 9.9 & 7.20 & 8.87 & 102 & 1.61 & 7.54 & 1.25 & 232 & 16.7 & 18.7 & 8.4 & 8.3 \\
\hline Blewbury & 9.9 & 7.04 & 7.02 & 131 & 2.08 & 7.26 & 2.45 & 268 & 26.8 & 39.8 & 13.2 & 12.1 \\
\hline Upton & 10.2 & 7.15 & 9.25 & 135 & 2.23 & 7.92 & 2.15 & 284 & 34.8 & 42.2 & 10.3 & 12.6 \\
\hline Ginge & 9.8 & 7.03 & 7.25 & 116 & 2.04 & 8.59 & 3.90 & 290 & 16.5 & 18.1 & 6.5 & 12 \\
\hline Letcombe B. & 9.7 & 7.21 & 8.30 & 97.3 & 1.61 & 6.64 & 1.69 & 250 & 11.9 & 14.3 & 5. & 11.8 \\
\hline Woolstone & 10.4 & 7.19 & 8.25 & 95.2 & 2.04 & 9.86 & 2.53 & 241 & 17.2 & 27.1 & 5.1 & 11.8 \\
\hline 12-Mar-07 & Temp & $\mathbf{p H}$ & DO & $\mathrm{Ca}$ & Mg & $\mathrm{Na}$ & $\mathbf{K}$ & $\mathrm{HCO}_{3}$ & Cl & $\mathrm{SO}_{4}$ & $\mathrm{NO}_{3}-\mathrm{N}$ & $\mathbf{S i}$ \\
\hline Kimber & 10.4 & 7.04 & 7.04 & 112 & 3.59 & 11.7 & 2.85 & 270 & 23.4 & 20.7 & 7.8 & 7.4 \\
\hline Jannaways & 10.2 & 7.00 & 7.85 & 123 & 2.25 & 9.15 & 2.29 & 315 & 18.8 & 16.7 & 8. & 7. \\
\hline Weston & 9.5 & 7.04 & 8.52 & 113 & 1.83 & 7.87 & 2.08 & 291 & 17.0 & 14.4 & 8. & 7. \\
\hline E Garston & 10.1 & 7.16 & 7.08 & 89.9 & 1.52 & 5.28 & 1.43 & 244 & 12.4 & 12.0 & 7. & 7. \\
\hline Lynch Wd & 9.9 & 7.15 & 8.65 & 101 & 1.59 & 7.08 & 1.59 & 252 & 15.7 & 19.0 & 7.6 & 7.4 \\
\hline Blewbury & 10.7 & 7.27 & 5.04 & 134 & 2.04 & 7.07 & 2.41 & 276 & 26.3 & 38.2 & 13.3 & 11.6 \\
\hline Upton & 9.9 & 7.27 & 7.15 & 141 & 2.19 & 7.94 & 1.94 & 286 & 32.9 & 41.7 & 10.8 & 11 \\
\hline Ginge & 10.6 & 7.06 & 6.43 & 126 & 2.16 & 8.92 & 4.49 & 305 & 15.9 & 19.4 & 6.3 & 12.4 \\
\hline Letcombe B. & 9.9 & 7.34 & 6.50 & 101 & 1.67 & 6.48 & 1.86 & 258 & 11.0 & 14.2 & 5. & 12.0 \\
\hline Woolstone & 10.5 & 7.06 & 6.16 & 105 & 2.19 & 10.0 & 2.67 & 311 & 15.7 & 28.4 & 4.5 & 13.1 \\
\hline 02-Oct-07 & Temp & pH & DO & Ca & Mg & $\mathrm{Na}$ & $\mathbf{K}$ & $\mathrm{HCO}_{3}$ & Cl & $\mathrm{SO}_{4}$ & $\mathrm{NO}_{3}-\mathrm{N}$ & $\mathbf{S i}$ \\
\hline Kimber & 10.6 & 7.07 & - & 110 & 4.09 & 12.1 & 4.86 & 271 & 23.2 & 20.3 & 7.6 & 8.0 \\
\hline Jannaways & 12.4 & 7.06 & - & 113 & 2.30 & 9.85 & 2.55 & 290 & 20.8 & 17.9 & 7. & 7.1 \\
\hline Weston & 11.1 & 7.11 & - & 106 & 1.82 & 7.89 & 2.26 & 271 & 16.2 & 12.3 & 7. & 8 \\
\hline E Garston & 10.0 & 7.23 & - & 91.8 & 1.53 & 5.83 & 1.22 & 226 & 12.5 & 12.8 & 7.7 & 8. \\
\hline Lynch Wd & 10.0 & 7.20 & - & 93.9 & 1.43 & 5.25 & 0.99 & 247 & 13.3 & 16.9 & 6.9 & 7.5 \\
\hline Blewbury & 10.6 & 7.08 & - & 122 & 2.03 & 6.7 & 2.43 & 250 & 26.2 & 39.6 & 13.6 & 11.6 \\
\hline $\mathrm{U}_{1}$ & & $7 .($ & - & 124 & 2 & 8.15 & 2 & 2 & 2 & 435 & 11.8 & 1 \\
\hline Gin & 1 & 7.1 & - & 98.7 & 1.76 & 6.63 & 3.1 & 27 & 12 & 14 & 5. & 12 \\
\hline Letcombe B & & 7.24 & - & 86.3 & 1.44 & 5.7 & 1.59 & 23 & 9.46 & 11 & 4. & \\
\hline Woolstone & 10.6 & 7.30 & - & 91.1 & 2.00 & 9.22 & 2.70 & 250 & 13.6 & 31.5 & 4.6 & 12.7 \\
\hline 03-Jan-08 & Temp & $\mathbf{p H}$ & DO & Ca & Mg & $\mathbf{N a}$ & $\mathbf{K}$ & $\mathrm{HCO}_{3}$ & Cl & $\mathrm{SO}_{4}$ & $\mathrm{NO}_{3}-\mathrm{N}$ & $\mathbf{S i}$ \\
\hline Kimber & 10.0 & 7.03 & - & 106 & 3.47 & 11.7 & 2.86 & 277 & 22.4 & 19.4 & 7.4 & 8.0 \\
\hline Jannaways & 8.8 & 7.12 & - & 115 & 2.09 & 9.96 & 2.52 & 290 & 22.5 & 17.8 & 8. & 6.9 \\
\hline Weston & 99 & 7.18 & - & 104 & 1.75 & 739 & 217 & 274 & 162 & 120 & 8. & 8. \\
\hline ston & 9.8 & 7.30 & - & 92.4 & 1.56 & 6.05 & 1.11 & 226 & 13.4 & 15.8 & 7. & 8. \\
\hline Lynch Wd & 9.7 & 7.22 & - & 91.6 & 1.38 & 5.04 & 0.93 & 232 & 12.7 & 15.9 & 6.5 & 7.5 \\
\hline Blewbury & 10.1 & 7.20 & - & 125 & 2.02 & 6.83 & 2.4 & 256 & 25.7 & 40.8 & 13.2 & 11. \\
\hline Upt & & 7.2 & - & 126 & 2.16 & 7.80 & 2.2 & 250 & 2 & & 10.8 & \\
\hline Gin & 10 & 7.3 & - & 95 & 1.68 & 6.54 & 299 & 25 & 12 & 133 & 5. & 12 \\
\hline Letcombe B. & 9.8 & 7.38 & - & 83.2 & 1.41 & 5.60 & 1.44 & 232 & 9.71 & 12.0 & 4.6 & 11.5 \\
\hline Woolstone & 10.1 & 7.35 & - & 97.4 & 2.53 & 7.99 & 3.01 & 232 & 13.9 & 40.7 & 5.4 & 12.8 \\
\hline 27-Mar-08 & Temp & pH & DO & $\mathrm{Ca}$ & Mg & $\mathrm{Na}$ & $\mathbf{K}$ & $\mathrm{HCO}_{3}$ & Cl & $\mathrm{SO}_{4}$ & $\mathrm{NO}_{3}-\mathrm{N}$ & $\mathbf{S i}$ \\
\hline & 10.3 & 7.21 & - & 98.7 & & 11.1 & 262 & & 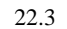 & 212 & 7.1 & 7. \\
\hline Jannaways & 9. & 7.25 & - & 108 & 1.99 & 8.73 & 2.01 & 310 & 19.1 & 18.1 & 8.3 & 6.5 \\
\hline Weston & 9.6 & 7.14 & - & 94.6 & 1.48 & 6.26 & 1.74 & 265 & 16.2 & 13.6 & 8.4 & 6.6 \\
\hline & 9.8 & 7.24 & - & 85.3 & 1.16 & 25 & 0.7 & 239 & 11.5 & 12 & 7. & 6. \\
\hline Lynch Wd & 9.8 & 7.34 & - & 93.7 & 1.41 & 5.42 & 0.95 & 259 & 13.6 & 18.7 & 7.2 & 7.1 \\
\hline Blewbury & 9.9 & 7.2 & - & 119 & 1.9 & 6.6 & 2.34 & 281 & 24.4 & 38.7 & 13.5 & 11.3 \\
\hline Upton & 9.2 & 7.08 & - & 124 & 2.05 & 7.63 & 1.93 & 280 & 27.0 & 43.0 & 11.4 & 11.9 \\
\hline Ginge & 10.5 & 7.21 & - & 101 & 1.78 & 7.38 & 3.59 & 297 & 13.5 & 16.5 & 5. & 11.9 \\
\hline Let & 9.9 & 7.39 & - & 86.8 & 1.43 & 5.85 & 1.44 & 258 & 9.98 & 12.8 & 4.6 & 11.6 \\
\hline Woolstone & 10.1 & 7.26 & - & 91.0 & 2.02 & 8.44 & 2.58 & 264 & 13.6 & 30.6 & 4.7 & 12.5 \\
\hline
\end{tabular}


Table 3. Field measurements and major and minor ion chemistry of borehole waters. DO - dissolved oxygen, TOC - total organic carbon.

\begin{tabular}{|c|c|c|c|c|c|c|c|c|c|c|c|c|c|c|c|c|c|}
\hline Site & $\begin{array}{c}\text { Temp } \\
{ }^{\circ} \mathrm{C} \\
\end{array}$ & pH & $\begin{array}{c}\text { DO } \\
\mathrm{mg} / \mathrm{L} \\
\end{array}$ & $\begin{array}{c}\mathrm{Ca} \\
\mathrm{mg} / \mathrm{L} \\
\end{array}$ & $\begin{array}{c}\mathrm{Mg} \\
\mathrm{mg} / \mathrm{L}\end{array}$ & $\begin{array}{c}\mathrm{Na} \\
\mathrm{mg} / \mathrm{L}\end{array}$ & $\begin{array}{c}\mathrm{K} \\
\mathrm{mg} / \mathrm{L} \\
\end{array}$ & $\begin{array}{c}\mathrm{HCO}_{3} \\
\mathrm{mg} / \mathrm{L}\end{array}$ & $\begin{array}{c}\mathrm{Cl} \\
\mathrm{mg} / \mathrm{L} \\
\end{array}$ & $\begin{array}{c}\mathrm{SO}_{4} \\
\mathrm{mg} / \mathrm{L} \\
\end{array}$ & $\begin{array}{c}\mathrm{NO}_{3}-\mathrm{N} \\
\mathrm{mg} / \mathrm{L}\end{array}$ & $\begin{array}{c}\mathrm{Si} \\
\mathrm{mg} / \mathrm{L} \\
\end{array}$ & $\begin{array}{c}\mathrm{Ba} \\
\mu \mathrm{g} / \mathrm{L} \\
\end{array}$ & $\begin{array}{c}\mathrm{Sr} \\
\mu \mathrm{g} / \mathrm{L}\end{array}$ & $\begin{array}{c}\mathrm{Br} \\
\mu \mathrm{g} / \mathrm{L} \\
\end{array}$ & $\begin{array}{c}F \\
\mu \mathrm{g} / \mathrm{L} \\
\end{array}$ & $\begin{array}{l}\text { TOC } \\
\mathrm{mg} / \mathrm{L}\end{array}$ \\
\hline \multicolumn{18}{|l|}{ Spring 2007} \\
\hline Barracks Farm & 11.2 & 7.40 & 0.63 & 59.9 & 7.76 & 28.9 & 4.23 & 259 & 7.9 & 21.1 & 1.15 & 12.3 & 5.7 & 1070 & 27 & 364 & 0.51 \\
\hline Bottom Barn & 10.7 & 7.42 & - & 116 & 1.58 & 7.07 & 1.12 & 293 & 17.8 & 12.4 & 8.60 & 6.52 & 18.8 & 247 & 39 & 114 & 0.19 \\
\hline Stocks Meadow Farm & 10.9 & 7.09 & 11.2 & 104 & 1.48 & 5.74 & 1.27 & 260 & 15.2 & 16.6 & 6.94 & 9.77 & 18.8 & 264 & 40 & 102 & 0.53 \\
\hline Rowbury Farm & 11.6 & 7.04 & - & 160 & 1.93 & 9.72 & 2.33 & 422 & 23.4 & 16.9 & 12.1 & 6.06 & 44.3 & 347 & 45 & 117 & 0.27 \\
\hline Seven Barrows Stables & 9.7 & 7.22 & 10.6 & 114 & 1.68 & 7.77 & 1.12 & 267 & 19.3 & 26.3 & 9.68 & 4.44 & 11.0 & 258 & 40 & 63 & 1.16 \\
\hline Cow Down & 11.1 & 6.70 & - & 86.4 & 0.767 & 4.45 & 0.84 & 234 & 9.4 & 2.9 & 2.67 & 8.42 & 14.1 & 154 & 29 & 67 & 0.44 \\
\hline \multicolumn{18}{|l|}{ Spring 2008} \\
\hline Barracks Farm & 11.8 & 6.74 & 7.5 & 60.0 & 7.17 & 28.3 & 4.11 & 267 & 8.4 & 21.0 & 1.99 & 11.7 & 6.7 & 994 & 51 & 336 & 0.95 \\
\hline Bottom Barn & 11.5 & 6.81 & - & 110 & 1.61 & 7.44 & 1.03 & 293 & 16.6 & 14.1 & 8.90 & 6.24 & 25.4 & 276 & 57 & 121 & 0.82 \\
\hline Stocks Meadow Farm & 7.3 & 7.11 & 12.1 & 100 & 1.45 & 5.90 & 1.25 & 265 & 15.1 & 16.2 & 7.74 & 9.76 & 16.9 & 270 & 67 & 122 & 1.00 \\
\hline Rowbury Farm & 11.7 & 7.26 & - & 143 & 1.85 & 9.53 & 2.20 & 427 & 21.1 & 17.7 & 11.4 & 5.27 & 36.7 & 321 & 57 & 121 & 12.4 \\
\hline Seven Barrows & 9.7 & 7.25 & 11.0 & 111 & 1.36 & 6.76 & 0.90 & 252 & 19.7 & 27.5 & 9.88 & 4.37 & 11.3 & 212 & 60 & 75 & 1.41 \\
\hline Cow Down & 11.5 & 7.10 & - & 81.9 & 0.75 & 4.64 & 0.86 & 219 & 9.6 & 3.8 & 2.96 & 8.46 & 13.3 & 155 & 45 & 88 & 0.79 \\
\hline
\end{tabular}


Table 4. Concentrations of dissolved CFCs and $\mathrm{SF}_{6}$ in spring waters.

\begin{tabular}{|c|c|c|c|c|c|c|c|c|c|c|c|c|}
\hline & \begin{tabular}{|l} 
CFC-12 \\
$\mathrm{pmol} / \mathrm{L}$
\end{tabular} & $\begin{array}{l}\text { 31-Oct-0 } \\
\text { CFC-11 } \\
\text { pmol/L }\end{array}$ & $\begin{array}{r}\mathrm{SF}_{6} \mathrm{c} \\
\mathrm{fmol} / \mathrm{L} \\
\end{array}$ & $\begin{array}{l}\text { CFC-12 } \\
\mathrm{pmol} / \mathrm{L} \\
\end{array}$ & $\begin{array}{l}\text { 30-Nov-0 } \\
\text { CFC-11 } \\
\text { pmol/L }\end{array}$ & $\begin{array}{r}\mathrm{SF}_{6} \mathrm{c} \\
\mathrm{fmol} / \mathrm{L} \\
\end{array}$ & $\begin{array}{l}\text { CFC-12 } \\
\mathrm{pmol} / \mathrm{L} \\
\end{array}$ & $\begin{array}{c}\text { 04-Jan-0 } \\
\text { CFC-11 } \\
\text { pmol/L } \\
\end{array}$ & $\begin{array}{r}\mathrm{SF}_{6} \mathrm{c} \\
\mathrm{fmol} / \mathrm{L}\end{array}$ & $\begin{array}{l}\text { CFC-12 } \\
\text { pmol/L }\end{array}$ & $\begin{array}{c}06-F e b-07 \\
\text { CFC-11 } \\
\text { pmol/L }\end{array}$ & $\begin{array}{r}\mathrm{SF}_{6} \mathrm{c} \\
\mathrm{fmol} / \mathrm{L} \\
\end{array}$ \\
\hline Valley springs & & & & & & & & & & & & \\
\hline Kimber & 18.3 & 32.0 & 1.09 & 10.2 & 23.4 & 1.12 & 11.0 & 31.3 & 1.09 & 14.2 & 32.2 & 1.37 \\
\hline Jannaways & 3.17 & 4.99 & 0.83 & 2.14 & 4.51 & 0.89 & 2.52 & 6.13 & 0.84 & 2.63 & 3.47 & 1.87 \\
\hline Weston & & & & & & & 7.74 & 53.8 & 1.18 & 6.45 & 37.6 & 1.65 \\
\hline East Garston & & & & & & & 2.82 & 13.4 & 1.29 & 3.47 & 7.09 & 1.42 \\
\hline Lynch Wood & & & & & & & 1.76 & 14.8 & 1.33 & 2.42 & 10.7 & 1.45 \\
\hline Scarp springs & & & & & & & & & & & & \\
\hline Blewbury & 15.8 & 108 & 1.36 & 11.7 & 85.9 & 0.87 & 13.5 & 155 & 1.36 & 14.2 & 91.0 & 1.75 \\
\hline Upton & & & & & & & 6.25 & 139 & 1.28 & 7.18 & 108 & 2.16 \\
\hline Ginge & 2.14 & 6.92 & 0.95 & 1.48 & 8.59 & 1.21 & 2.13 & 12.9 & 1.34 & 2.02 & 17.1 & 1.65 \\
\hline Letcombe Bassett & 1.32 & 3.04 & 1.16 & 0.88 & 3.75 & 1.03 & 1.15 & 6.88 & 1.18 & 1.37 & 5.83 & 1.43 \\
\hline Woolstone & & & & 0.71 & 5.62 & 0.89 & 1.27 & 8.26 & 0.99 & 0.71 & 8.44 & 1.59 \\
\hline & $\begin{array}{l}\text { CFC-12 } \\
\mathrm{pmol} / \mathrm{L}\end{array}$ & $\begin{array}{l}\text { 12-Mar-0 } \\
\text { CFC-11 } \\
\mathrm{pmol} / \mathrm{L} \\
\end{array}$ & $\begin{array}{r}\mathrm{SF}_{6} \mathrm{c} \\
\mathrm{fmol} / \mathrm{L}\end{array}$ & \begin{tabular}{|l} 
CFC-12 \\
$\mathrm{pmol} / \mathrm{L}$
\end{tabular} & $\begin{array}{c}\text { 02-Oct-0 } \\
\text { CFC-11 } \\
\text { pmol/L } \\
\end{array}$ & $\begin{array}{r}\mathrm{SF}_{6} \mathrm{c} \\
\mathrm{fmol} / \mathrm{L} \\
\end{array}$ & $\begin{array}{l}\mathrm{CFC}-12 \\
\mathrm{pmol} / \mathrm{L}\end{array}$ & $\begin{array}{c}\text { 03-Jan-0 } \\
\text { CFC-11 } \\
\text { pmol/L } \\
\end{array}$ & $\begin{array}{r}\mathrm{SF}_{6} \mathrm{c} \\
\mathrm{fmol} / \mathrm{L}\end{array}$ & $\begin{array}{l}\mathrm{CFC}-12 \\
\mathrm{pmol} / \mathrm{L}\end{array}$ & $\begin{array}{l}\text { 27-Mar-0 } \\
\text { CFC-11 } \\
\text { pmol/L } \\
\end{array}$ & $\begin{array}{r}\mathrm{SF}_{6} \mathrm{c} \\
\mathrm{fmol} / \mathrm{L}\end{array}$ \\
\hline Valley springs & & & & & & & & & & & & \\
\hline Kimber & 9.67 & 27.9 & 1.38 & 13.7 & 35.4 & 1.15 & 13.6 & 18.1 & 1.13 & 16.3 & 40.9 & 1.06 \\
\hline Jannaways & 2.40 & 4.67 & 1.85 & 2.67 & 4.86 & 1.44 & 2.77 & 3.03 & 1.03 & 3.25 & 7.26 & 0.75 \\
\hline Weston & 6.76 & 44.8 & 1.52 & 7.99 & 38.8 & 2.64 & 7.19 & 23.2 & 0.28 & 5.37 & 49.2 & 0.71 \\
\hline East Garston & 3.24 & 6.54 & & 2.72 & 5.97 & 0.86 & 3.09 & 5.24 & 0.35 & 3.68 & 7.85 & 1.83 \\
\hline $\begin{array}{l}\text { Lynch Wood } \\
\text { Scarp springs }\end{array}$ & 1.88 & 13.9 & 1.50 & 1.27 & 10.5 & 1.27 & 2.50 & 6.31 & 0.64 & 2.73 & 12.5 & 2.38 \\
\hline Blewbury & 11.5 & 113 & & 12.0 & 90.6 & 1.51 & 17.7 & 48.9 & 0.66 & 16.6 & 97.1 & 0.61 \\
\hline Upton & 8.05 & 140 & 1.49 & 673 & 103 & 1.64 & 16.1 & 54.2 & 1.43 & 20.6 & 104 & 0.56 \\
\hline Ginge & 2.07 & 11.0 & 1.57 & 1.76 & 14.4 & 1.37 & 2.00 & 6.70 & 0.76 & 3.85 & 13.3 & 0.80 \\
\hline Letcombe Bassett & 1.56 & 7.73 & 1.34 & 1.32 & 4.9 & 1.18 & 1.44 & 2.80 & 1.14 & 2.01 & 4.87 & 1.03 \\
\hline Woolstone & 0.96 & 7.70 & 1.60 & 0.60 & 7.81 & 1.27 & 1.02 & 3.87 & 1.12 & 1.51 & 8.75 & 0.55 \\
\hline
\end{tabular}

$\mathrm{SF}_{6} \mathrm{c}$ refers to concentrations corrected for excess air inputs

$\mathrm{pmol} / \mathrm{L}=10^{-12}$ moles per litre

$\mathrm{fmol} / \mathrm{L}=10^{-19}$ moles per litre 
Table 5. CFC-12 and $\mathrm{SF}_{6}$ data from Table 4 converted into modern fraction values (see text) and also notional piston flow ages. Air equilibrated water (aew) values refer to the maximum concentrations based on the assumption of recharge at a mean annual air temperature of $10^{\circ} \mathrm{C}$ and an average atmospheric mixing ratio based on data from http://water.usgs.gov/lab/software/air_curve/.

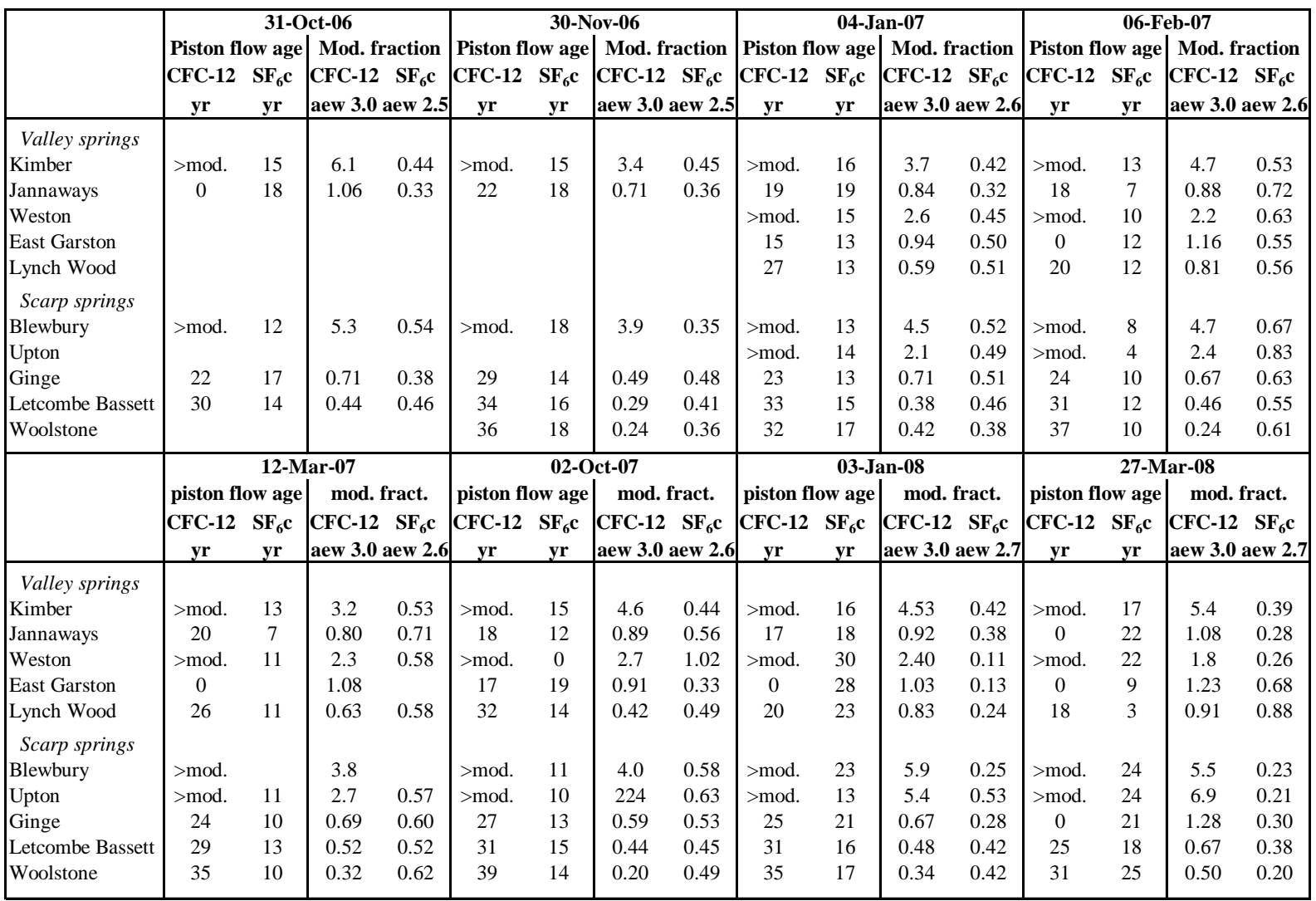




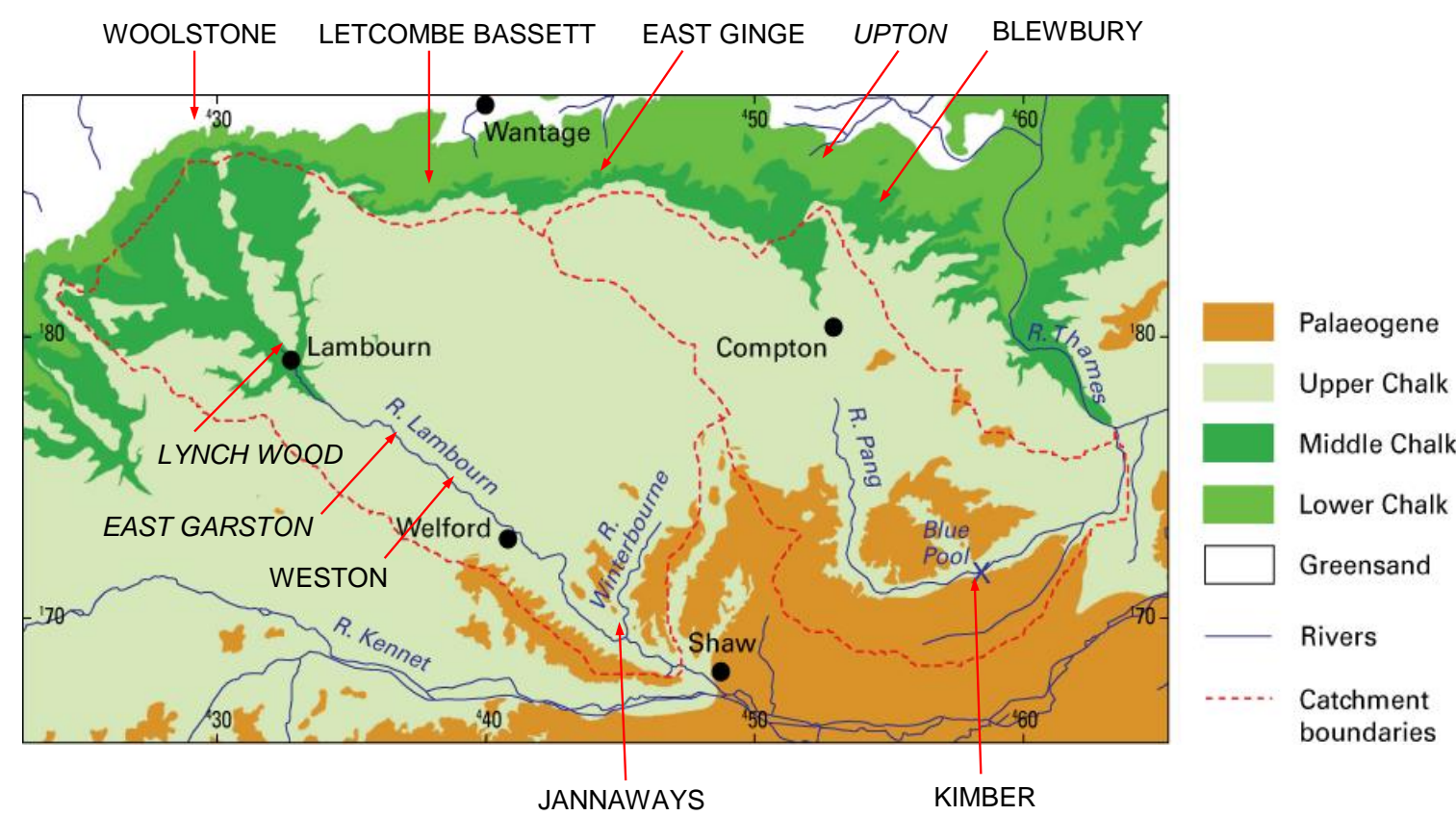

Fig. 1. Map of the Chalk in the Pang and Lambourn catchments, with the locations of valley and scarp spring indicated. Names of normally seasonal springs are shown in italics. Tick marks indicate $10 \mathrm{~km}$ grid. 


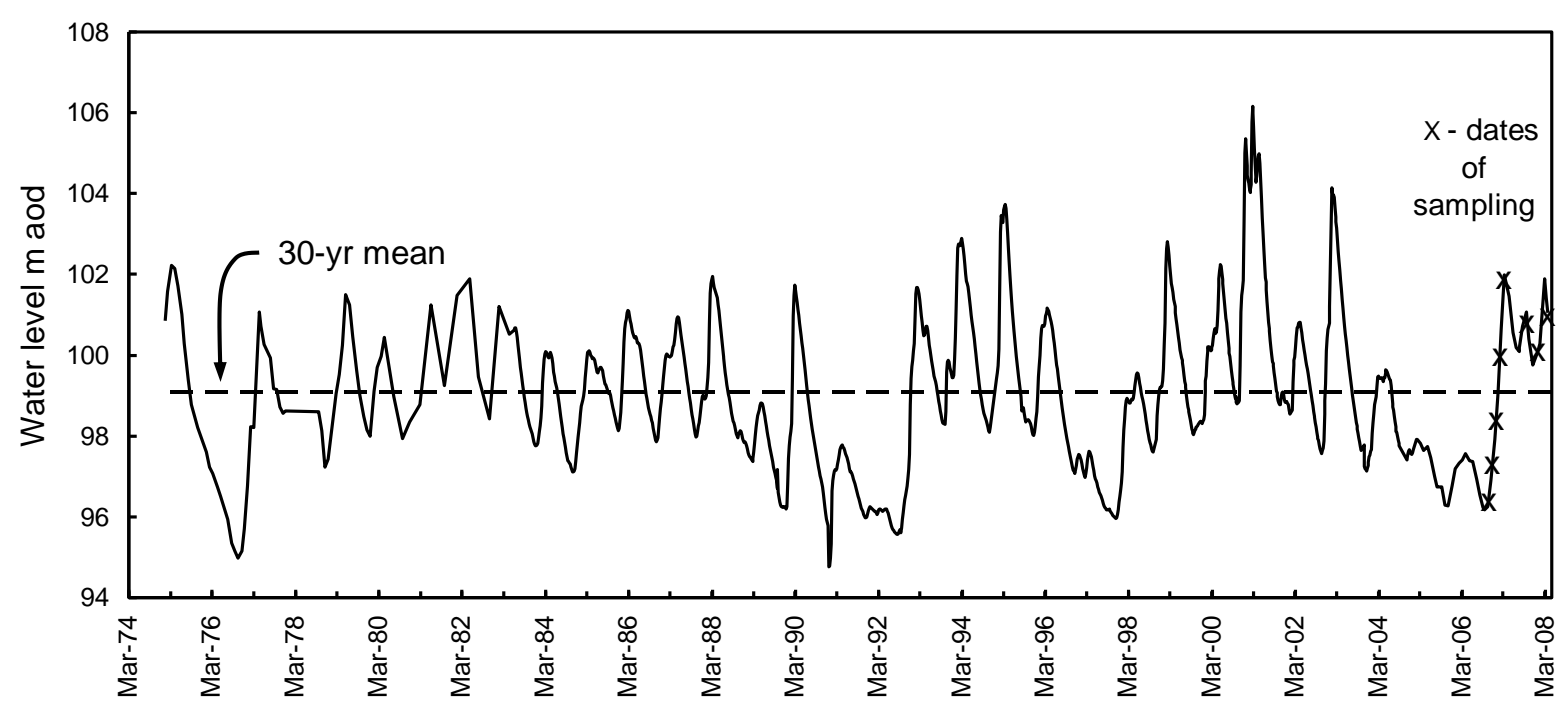

Fig. 2. Groundwater levels in the Bradley Wood borehole of the Lambourn catchment over the period January 1975 to March 2008, showing that the 2006-07 recovery commenced from a 10-year low point. Data courtesy of the Environment Agency. Also shown are the dates of spring sampling during the recovery. 

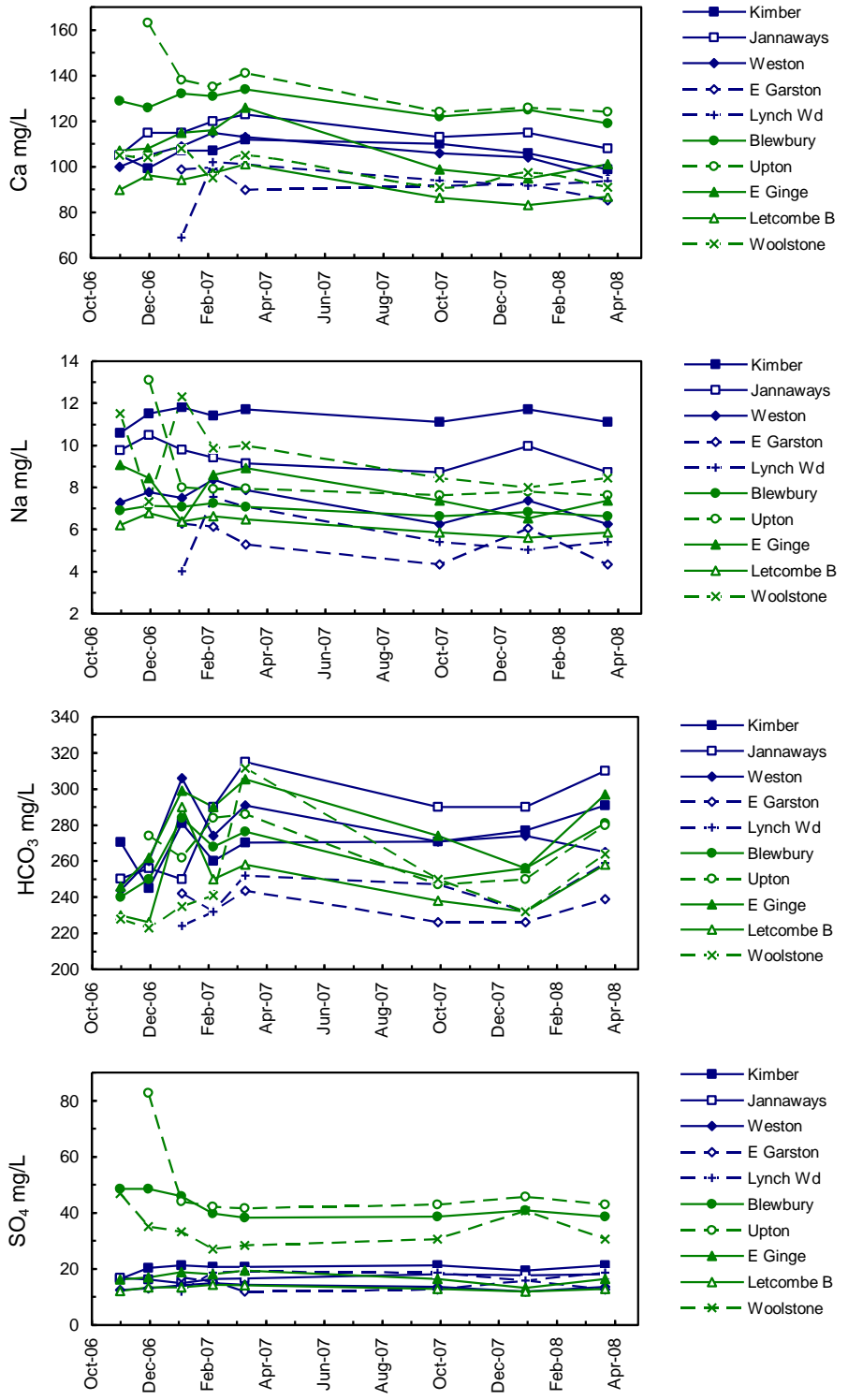

$\longrightarrow$ Kimber

$\longrightarrow$ W W

$-\diamond-E$ Garston

- + - Lynch Wd

$\longrightarrow$ Blewbury

- - - Upton

$\longrightarrow$ E Ginge

$\triangle$ - Letcombe B

$-*$ Woolstone

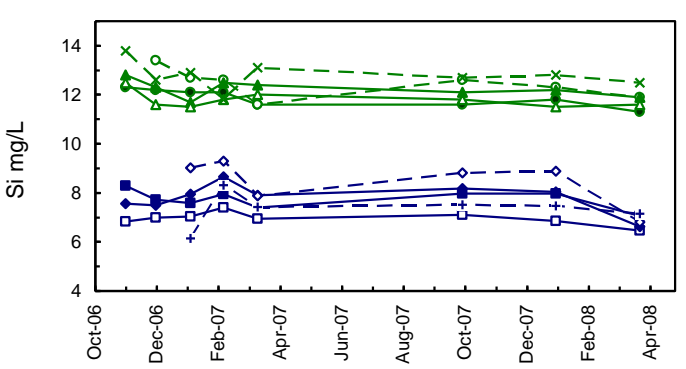

$\longrightarrow$ - Jannaways

$\longrightarrow$ Weston -+- Lynch Wd

$\longrightarrow$ Blewbury $-\curvearrowleft-$ Upton $\longrightarrow$ E Ginge $\longrightarrow$ Letcombe $\mathrm{B}$ - * Woolstone
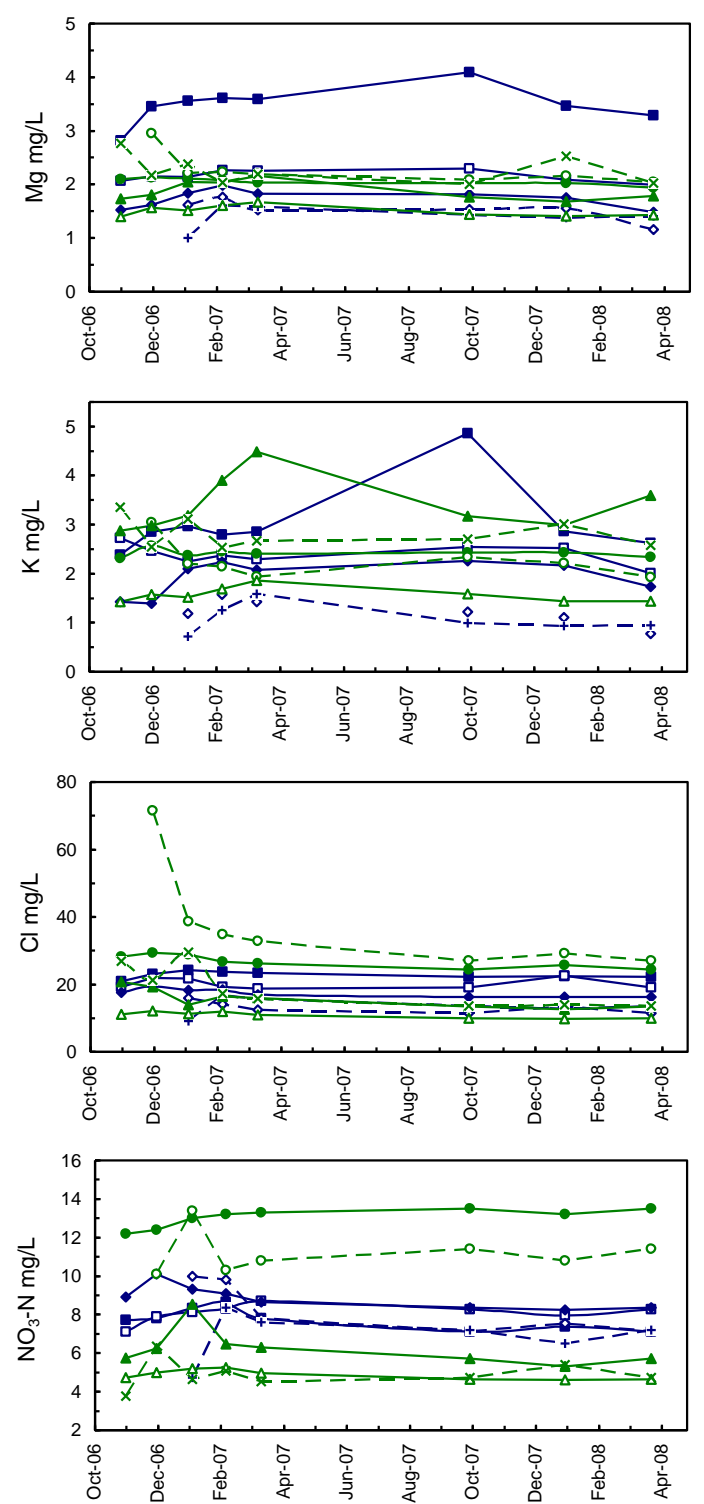

$\longrightarrow$ Kimber

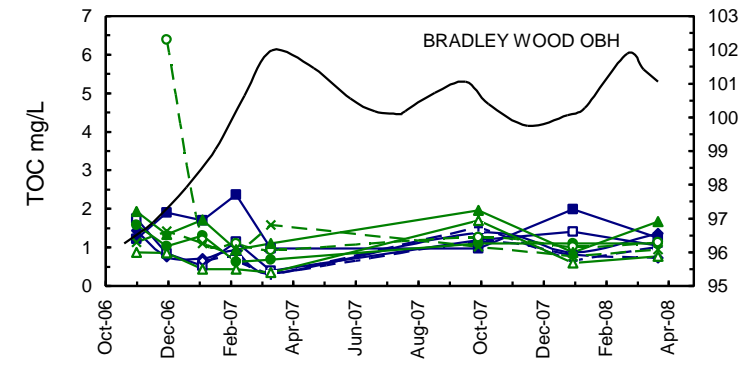

Fig. 3. Plots of major ions and total organic carbon (TOC) in spring waters from valley and scarp springs in and adjacent to the Pang and Lambourn catchments. The water level (in $\mathrm{m}$ aod) in the Bradley Wood observation borehole is shown on the TOC plot for reference. 

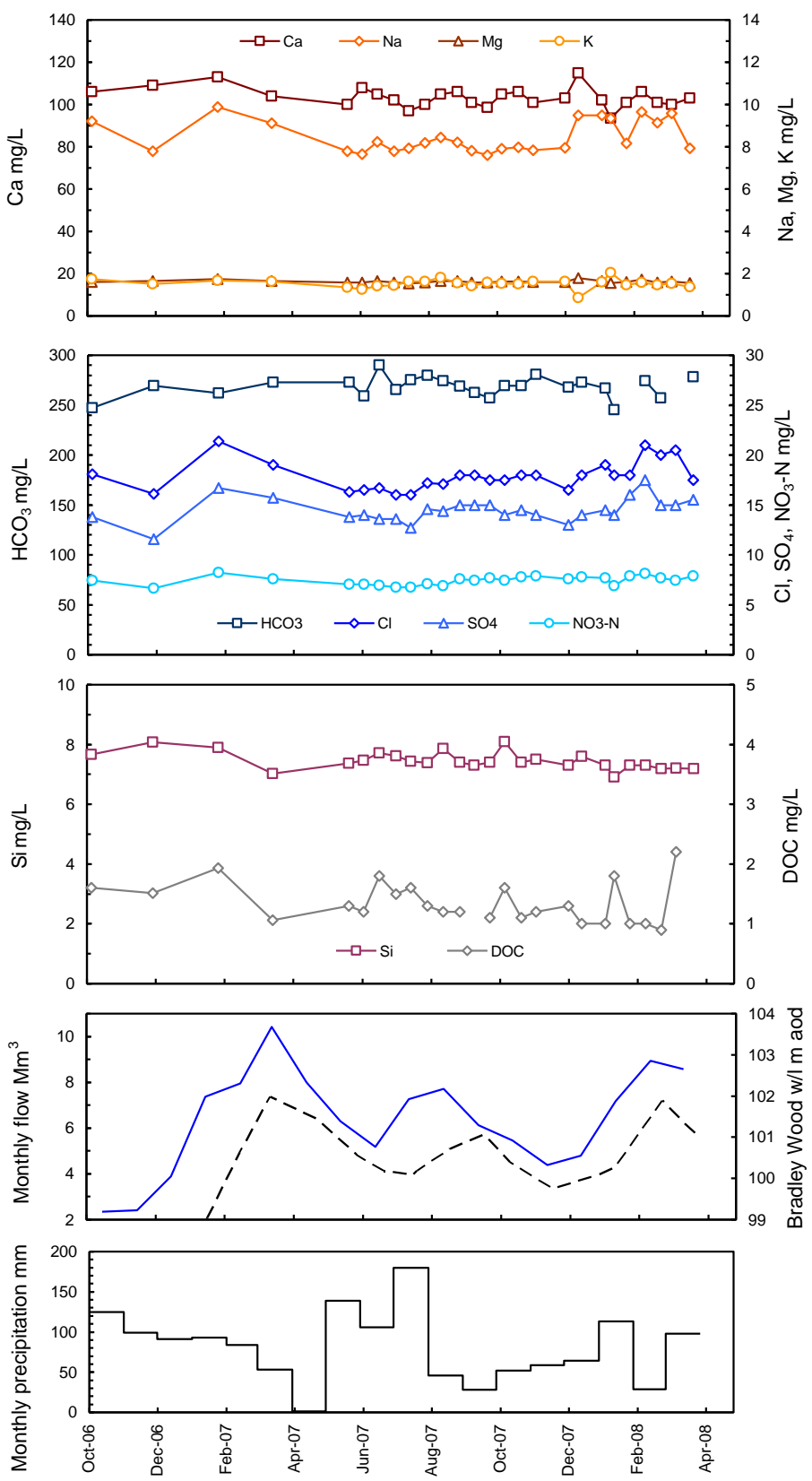

Fig. 4. Plots of major ions and dissolved organic carbon (DOC) in the River Lambourn at Boxford. Also shown for reference are monthly flow in the river (solid line), the water level in the Bradley Wood observation borehole (broken line), and the amount of monthly precipitation at the Wallingford meteorological site. 

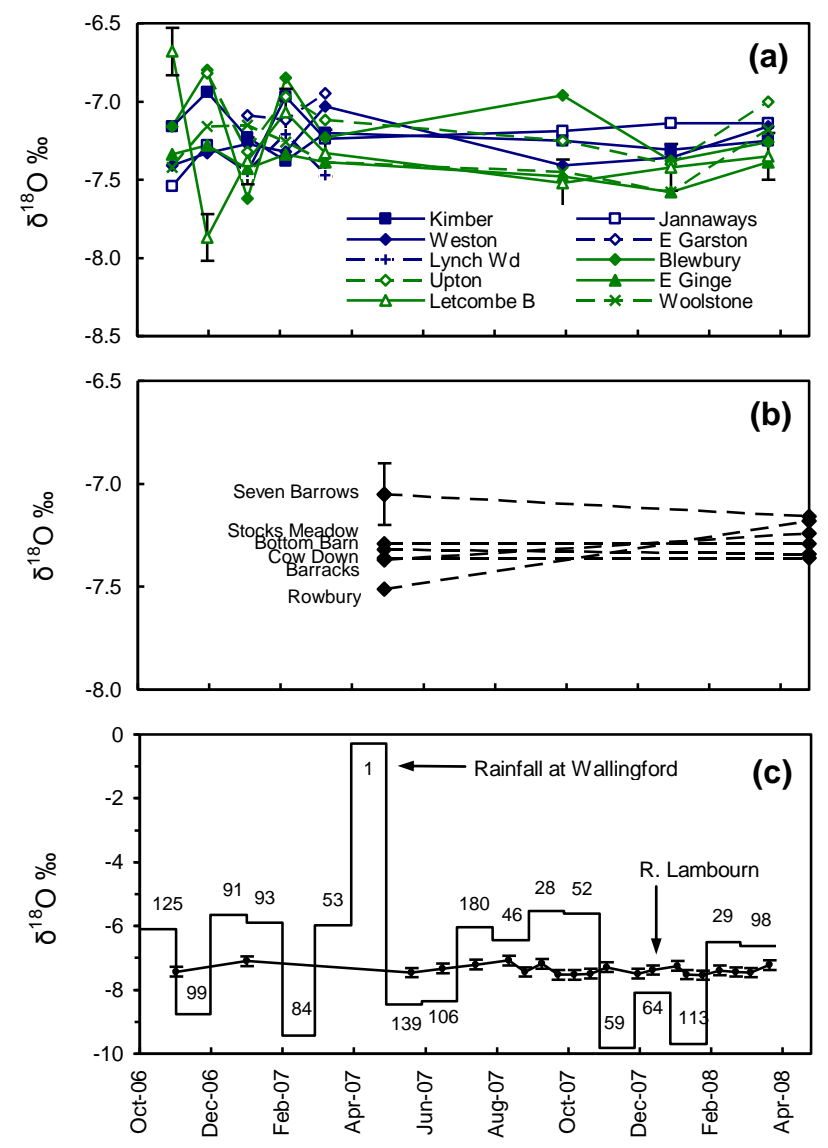

Fig. 5. Plots of $\delta^{18} \mathrm{O}$ for (a) valley and scarp springs, (b) boreholes and (c) the River Lambourn around the time of the recovery. Also shown in (c) is the monthly rainfall record from the Wallingford meteorological site labelled with amounts in mm (data from http://nds121.iaea.org/wiser/index.php). 

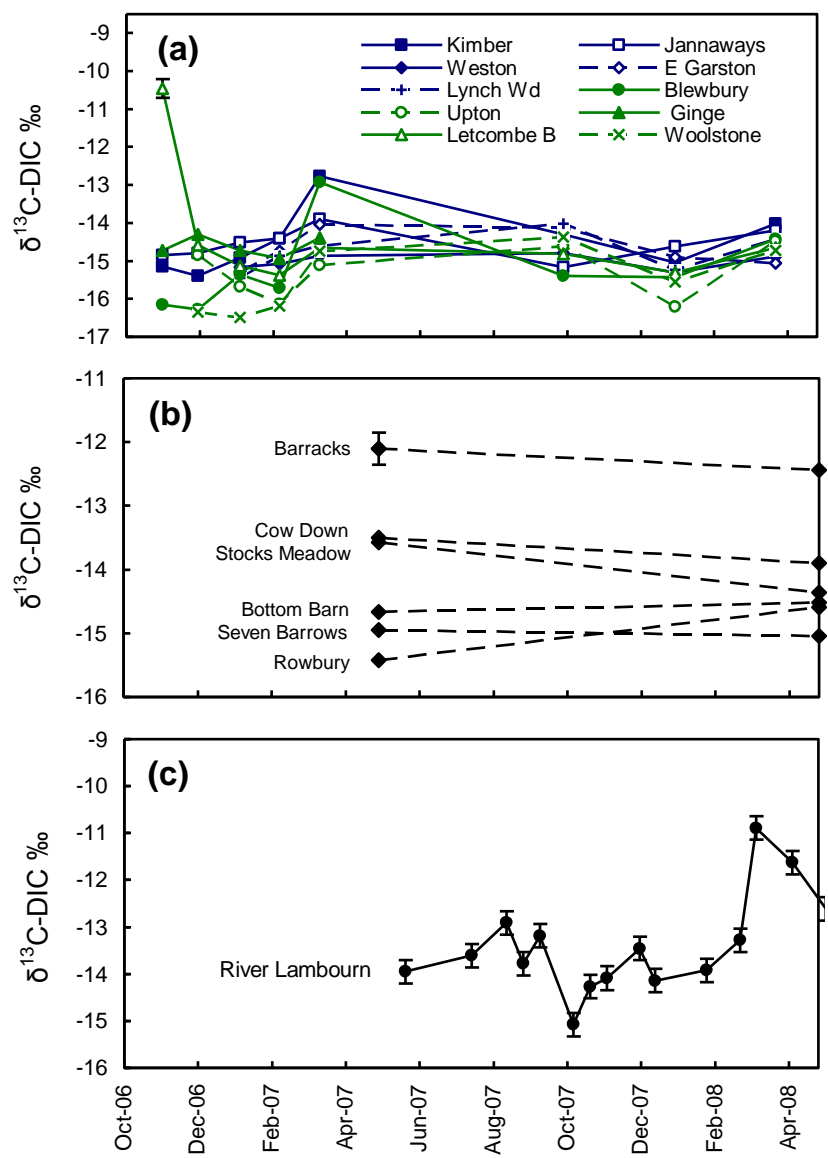

Fig. 6. Plots of $\delta^{13} \mathrm{C}_{\text {DIC }}$ for (a) valley and scarp springs, (b) boreholes and (c) the River Lambourn around the time of the recovery. 

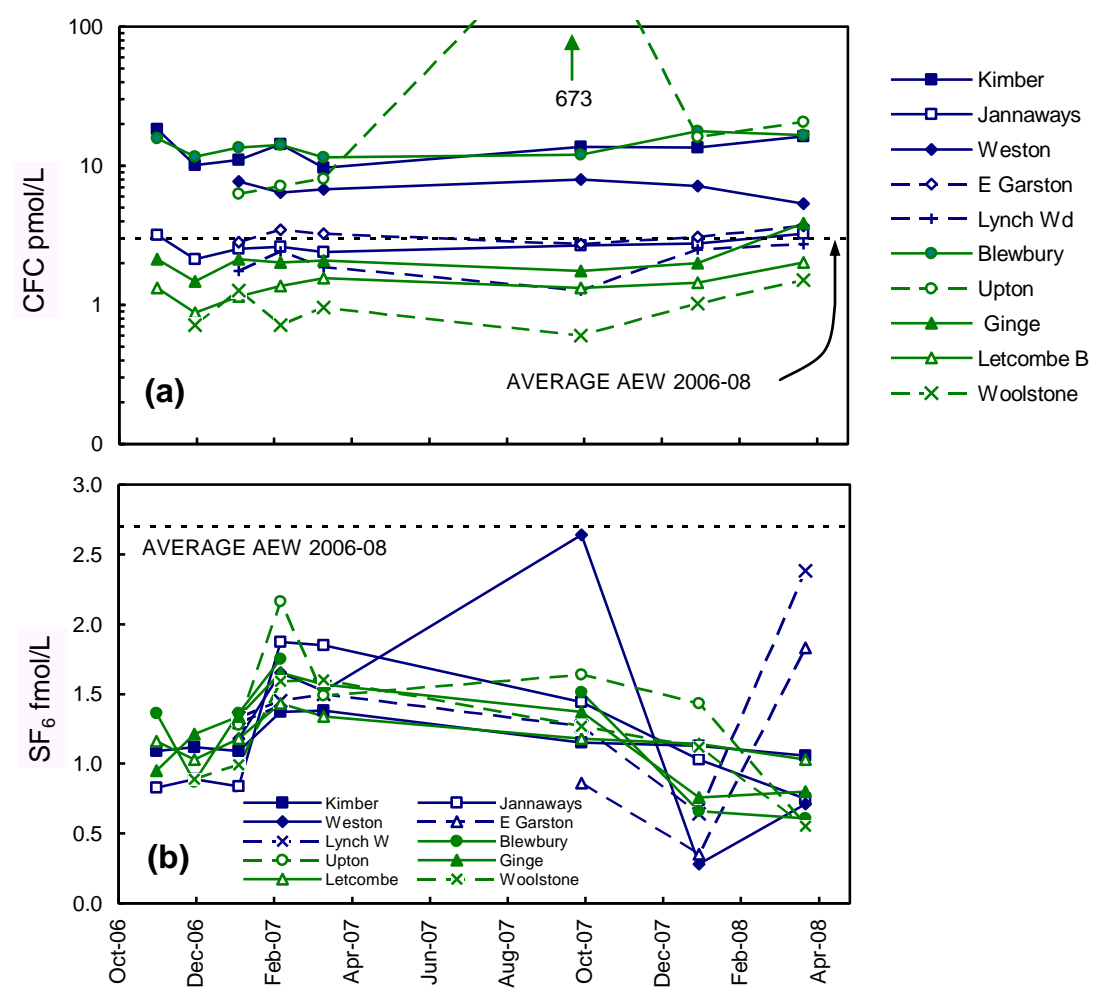

Fig. 7. Trace gas concentrations in valley and scarp springs: (a) CFC-12, (b) $\mathrm{SF}_{6}$. In both plots the average air-equilibrated water (AEW) concentration is shown, based on the assumption of recharge at a mean annual air temperature of $10^{\circ} \mathrm{C}$ and an average atmospheric mixing ratio based on data from http://water.usgs.gov/lab/software/air_curve/. 


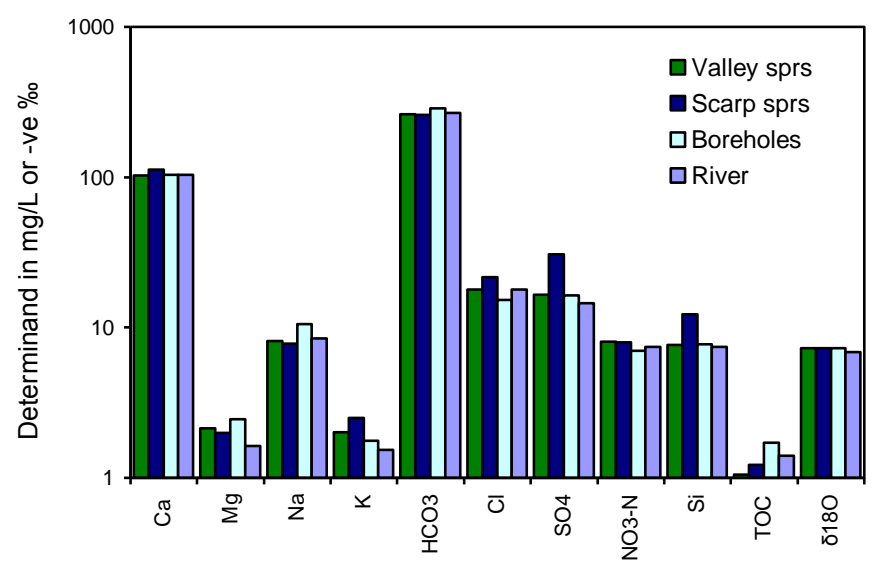

Fig. 8. Plot showing the similarity between average major ion and $\delta^{18} \mathrm{O}$ concentrations in waters from springs, boreholes and the River Lambourn. $\left(\delta^{18} \mathrm{O}\right.$ is plotted in 'negative permil' (-ve \%o) to fit the log ordinate.) 


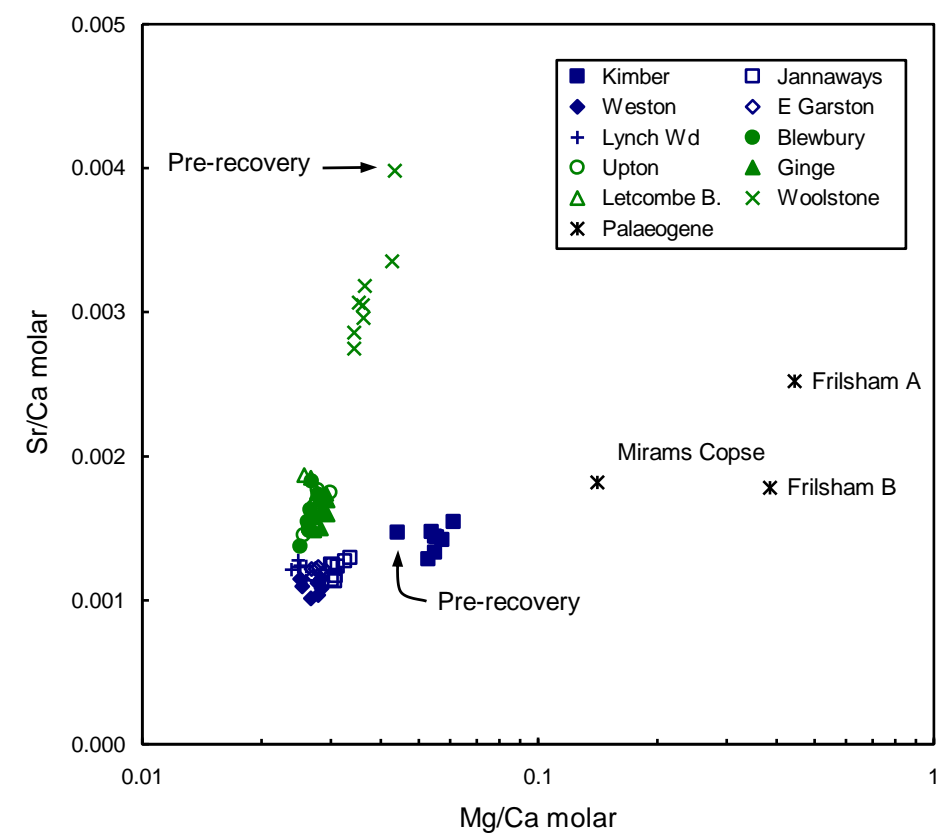

Fig. 9. Plot of molar $\mathrm{Sr} / \mathrm{Ca}$ versus $\mathrm{Mg} / \mathrm{Ca}$ showing two different processes affecting spring water quality: incongruent dissolution controls scarp spring compositions, while simple mixing with Palaeogene waters predominates in the valley springs. 


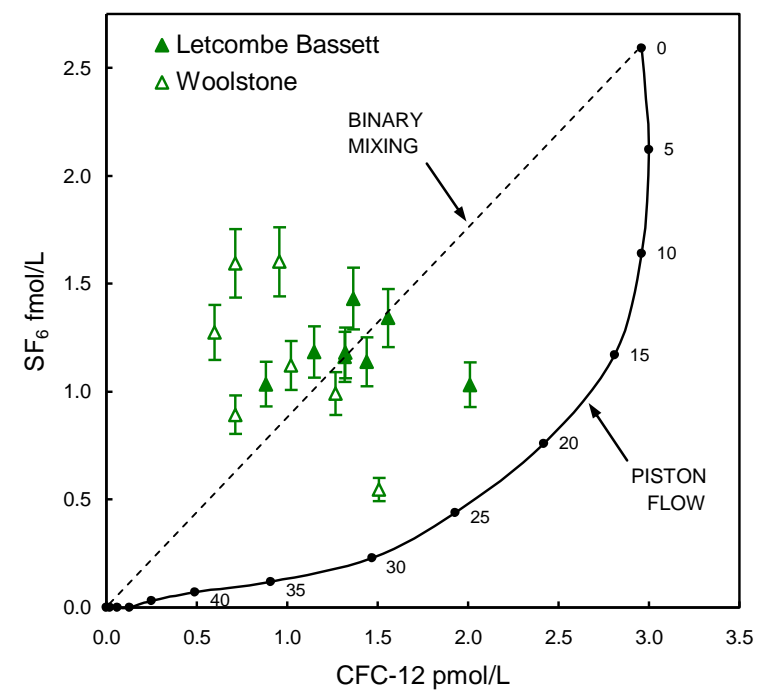

Fig. 10. Plot of CFC-12 versus $\mathrm{SF}_{6}$ for waters from the least $\mathrm{CFC}$-enhanced Chalk springs (Letcombe Bassett and Woolstone) showing a tendency to plot around the binary mixing line between modern and old (pre-1950s) groundwater. Also shown is the curve for simple piston flow with residence times in years. 

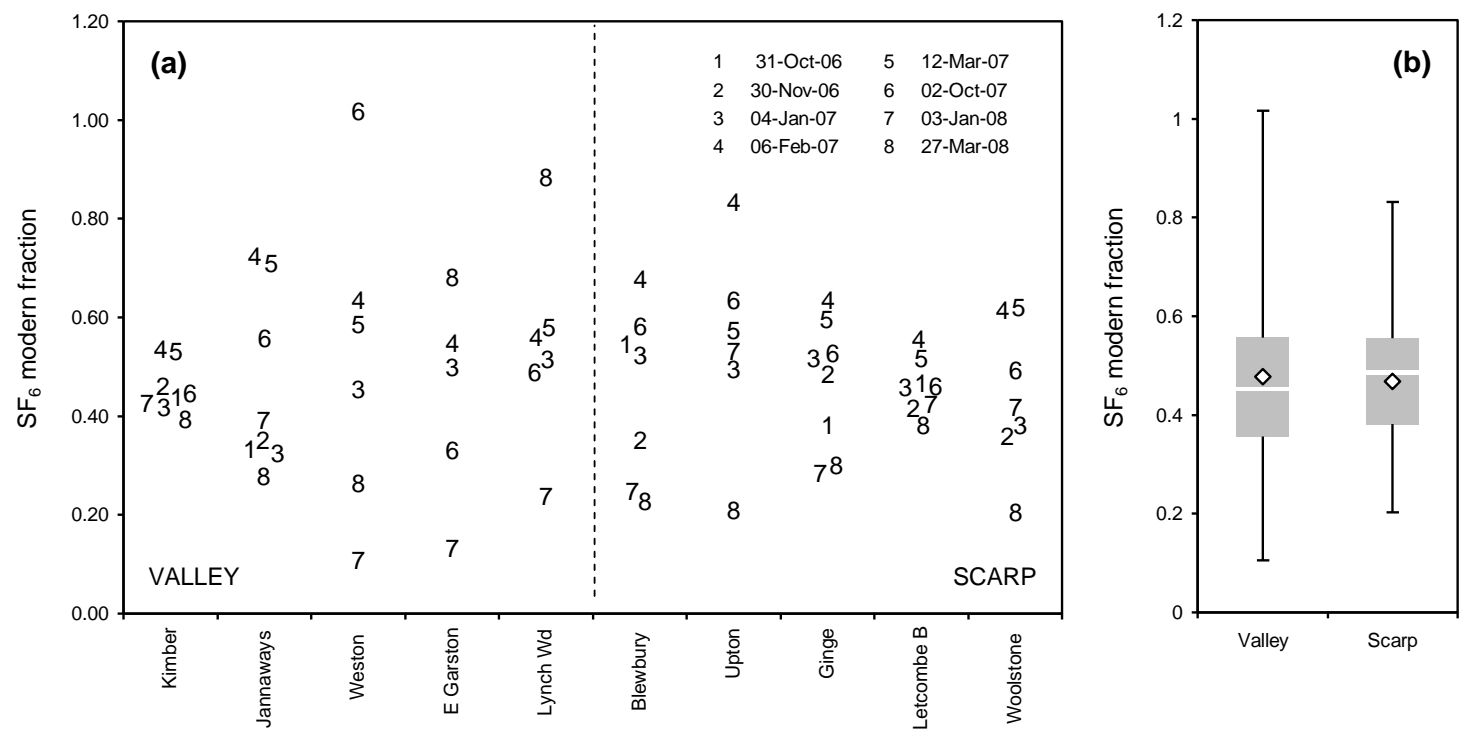

Fig. 11. Modern fraction (proportion of young water) in valley and scarp springs based on $\mathrm{SF}_{6}$ measurements: (a) numbers denote the modern fraction at individual sampling dates, (b) a statistical summary of the data showing mean, median, 25th and 75th percentiles and total range. 